\title{
35. UPPER MIOCENE TO HOLOCENE OXYGEN AND CARBON ISOTOPIC STRATIGRAPHY OF SITES 646 AND 647, LABRADOR SEA ${ }^{1}$
}

\author{
A. E. Aksu² and C. Hillaire-Marcel ${ }^{3}$
}

\begin{abstract}
Oxygen and carbon isotopic compositions of planktonic foraminifers Neogloboquadrina pachyderma and N. atlantica were determined at approximately $150-\mathrm{cm}$ intervals through late Pliocene to Holocene sediments in Hole $647 \mathrm{~A}$ and late Miocene to Holocene sediments in Hole 646B. The isotopic record shows an overall enrichment of about $4.0 \% 0$ in $\delta^{18} \mathrm{O}$ and $1.0 \% 0$ in $\delta^{13} \mathrm{C}$ from the base to top of Hole 646B. In general, this enrichment probably represents the progressive climatic cooling that started in the middle and late Miocene, continued throughout the Pliocene, and led to the Pleistocene glaciations. The $\delta^{18} \mathrm{O}$ values in sediments from approximately 2.66 to $2.42 \mathrm{Ma}$ show a considerable enrichment $(\sim 2.5 \%)$ and little change in the $\delta^{13} \mathrm{C}$ values, which probably reflects significant long-term ice storage in the Northern Hemisphere. We interpreted enrichments of $\sim 1.5 \%$ in $\delta^{18} 0$ and $\sim 1.0 \%$ in $\delta^{13} \mathrm{C}$ at $\sim 3.2 \mathrm{Ma}$, associated with minor ice-rafted material, as substantial cooling of surface waters in the Labrador Sea. Near the upper part of magnetochron 10 in Hole 646B, we observed an approximately 2 to $3 \%$ enrichment in the $\delta^{18} \mathrm{O}$, which is associated with a much smaller enrichment of $\sim 1.0 \% 0$ in the $\delta^{13} \mathrm{C}$. This correlates with the right-to-left coiling change in $N$. atlantica. We do not completely understand the cause of the large shift in isotopic record.
\end{abstract}

\section{INTRODUCTION}

In recent years, several papers were published about the oxygen and carbon isotopic records of Miocene to Holocene sediments in the central North Atlantic (Shackleton et al., 1984; Shackleton and Hall, 1984; Keigwin, 1987; Keigwin et al., 1987). The salient conclusions of these papers can be summarized as follows.

1. Unlike the earlier conclusion of Shackleton and Opdyke (1977) that significant North Atlantic glaciations occurred as early as 3.2 Ma, data from Deep Sea Drilling Project (DSDP) Hole 552A illustrated that the first major glaciation and ice rafting in the North Atlantic occurred at $2.37 \mathrm{Ma}$ (Shackleton et al., 1984; Shackleton and Hall, 1984). Oxygen isotopic data from DSDP Site 606 also confirm the Northern Hemisphere glacial advances at about 2.4 and $2.6 \mathrm{Ma}$ (Keigwin, 1987).

2. Benthic and planktonic isotopic results from DSDP Site 606 also indicate a considerable enrichment in the $\delta^{18} \mathrm{O}$ values at $\sim 3.1 \mathrm{Ma}$, some of which is attributed to cooling of the North Atlantic Deep Water and the remainder to minor glacial advance in the Northern Hemisphere (Keigwin, 1987).

3. Brief episodes of continental glaciations generally lasting less than 20,000 yr occurred at about 5.0 and 5.5 Ma (Keigwin et al., 1987).

This study examines the oxygen and carbon isotopic records of Ocean Drilling Program (ODP) Sites 646 and 647, compares the results with those obtained from DSDP Legs 81 and 94, and discusses the paleoenvironmental significance of the stable isotopic results.

The Labrador Sea is located adjacent to major Northern Hemisphere Pliocene-Pleistocene ice masses. It forms the west-

\footnotetext{
${ }^{1}$ Srivastava, S. P., Arthur, M., Clement, B., et al., 1989. Proc. ODP, Sci. Results, 105: College Station, TX (Ocean Drilling Program).

2 Department of Earth Sciences, Centre for Earth Resources Research, Memorial University of Newfoundland, St. John's, Newfoundland A1B 3X5, Canada.

${ }^{3}$ Département des Sciences de la Terre GEOTOP, Université du Québec à Montréal, CP 8888 Succursale "A," Montréal, Québec H3C 3P8, Canada.
}

ern branch of the Atlantic Ocean and constitutes a major conduit between the Arctic and Atlantic oceans, thus providing a unique opportunity to study the paleoceanographic history of the northwest Atlantic Ocean.

During Leg 105, four holes were drilled at two sites in the Labrador Sea (Fig. 1). Site 646 was drilled on the flank of the Eirik Ridge, one of a number of sediment drifts that occur around the northwest Atlantic Ocean. Holes 646A and 646B were terminated at 103.5 meters below seafloor (mbsf) and 766.7 mbsf, respectively. Site 647 is located approximately $100 \mathrm{~km}$ south of the Gloria Drift in the southern Labrador Sea. Holes 647A and 647B were drilled to a depth of 716.6 and $103.3 \mathrm{mbsf}$, respectively.

\section{MATERIAL AND TECHNIQUES}

To determine the oxygen- and carbon-isotope stratigraphy of the Miocene to Holocene sediments recovered in these Labrador Sea sites, about $10 \mathrm{~cm}^{3}$ of sediment was sampled at a depth of about every $150 \mathrm{~cm}$ in most core sections of Holes 646B and the upper $165 \mathrm{~m}$ in Hole 647A.

Foraminifer data in Hole 646B indicated that there were two planktonic foraminifer species $(N$. pachyderma sinistral and $N$. atlantica sinistral) suitable for stable isotopic determinations (Aksu and Kaminski, this volume). Except for shorter intervals barren of foraminifers, $N$. pachyderma (sinistral) occurred in high abundances and was present in Cores 105-646B-1H through 105-646B-19X. Samples from Cores 105646B-21X and 105-646B-22X were barren of foraminifers. Below Core $105-646 \mathrm{~B}-22 \mathrm{X}$, the abundance of $N$. pachyderma was low and its occurrence was sporadic, whereas $N$. atlantica (sinistral) was abundant in most samples. Oxygen and carbon isotopic variations in Hole 646B were determined using $N$. pachyderma (sinistral) in the upper $\sim 188 \mathrm{~m}$ and $N$. atlantica between $\sim 188$ and $766 \mathrm{~m}$. A few samples contained sufficient quantities of both $N$. pachyderma and $N$. atlantica to allow a calibration to be established between these species. All samples examined in Site 647 included high abundance of $N$. pachyderma (sinistral).

Sediment samples were dried in an oven at approximately $40^{\circ} \mathrm{C}$ for $24 \mathrm{hr}$. Subsequently, the sediment was dispersed in distilled water with about $10 \mathrm{~cm}^{3}$ of $1 \%$ Calgon solution. All samples were wet sieved through a $63 \mu \mathrm{m}$-screen, and the coarse fractions were dried in an oven. After determining foraminifer assemblages (Aksu and Kaminski, this volume), about 250 to 500 specimens of $N$. pachyderma and/or $N$. atlantica were handipicked from each sample for stable isotopic analyses. In a few samples, these stable isotopic analyses were performed on 


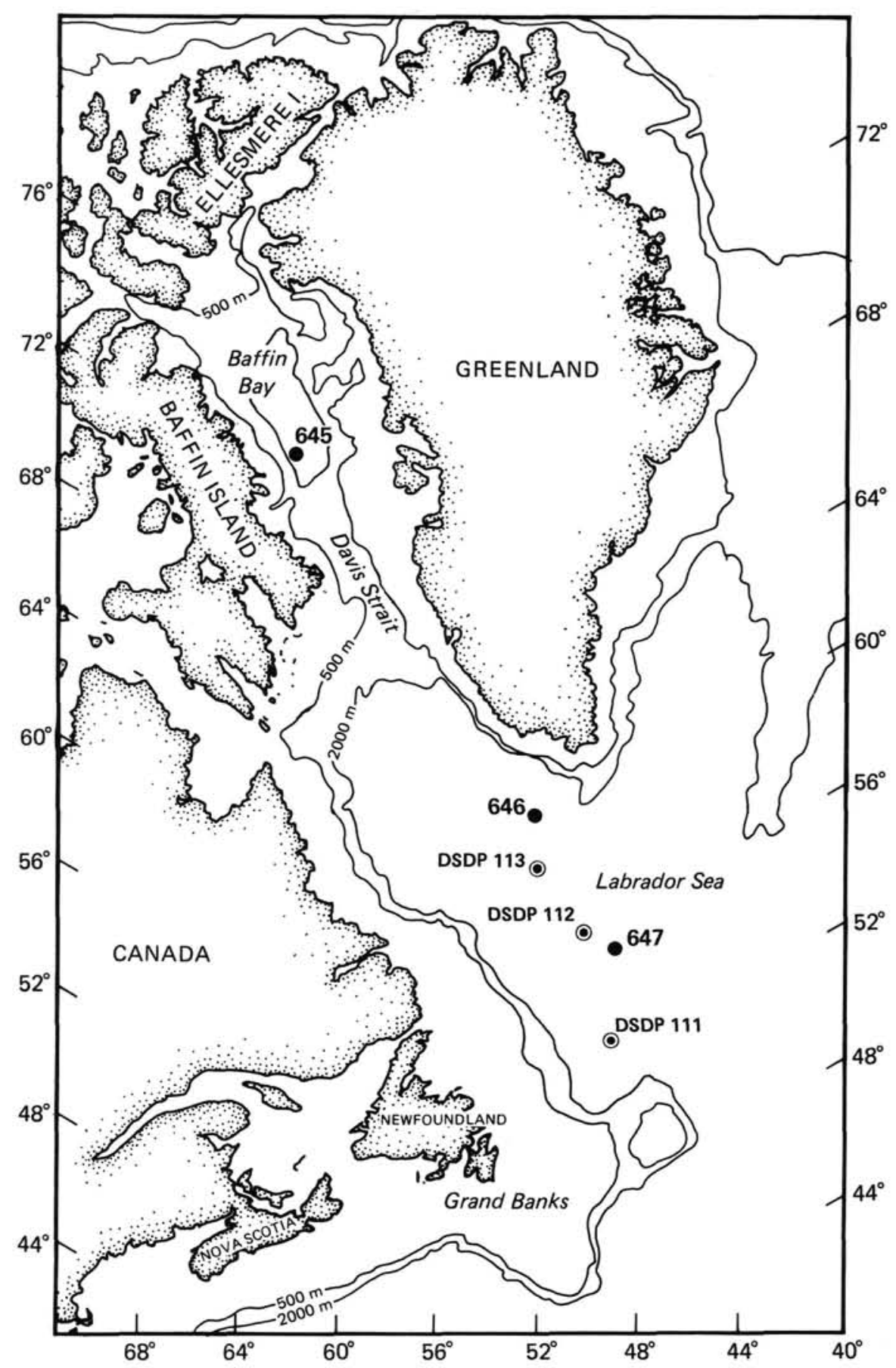

Figure 1. Location of Holes 646B and 647A.

$<100$ specimens. The foraminifer shells were cleaned in distilled water and dried in an oven at $90^{\circ} \mathrm{C}$. Foraminifer shells were transferred into double-arm reaction vessels and placed in water at $50^{\circ} \mathrm{C}$ for about $2 \mathrm{hr}$. They were acidified with $100 \%$ phosphoric acid. The reaction vessels were transferred into a vacuum line where the water in the evolved $\mathrm{CO}_{2}$ was trapped with a dry ice and methanol mixture $\left(\sim-85^{\circ} \mathrm{C}\right)$. The purified $\mathrm{CO}_{2}$ was collected in 6-mm pyrex tubes, then sealed and stored for stable isotopic analyses. The isotopic ratios of ${ }^{18} \mathrm{O} /{ }^{16} \mathrm{O}$ and ${ }^{13} \mathrm{C} /{ }^{12} \mathrm{C}$ were determined using a VG Micromass $903 \mathrm{E}$ triple collector mass spectrometer at the Memorial University of Newfoundland. Several duplicate analyses performed on the laboratory standard Carrara Marble and selected samples showed that the reproducibility varied from \pm 0.04 to \pm 0.08 . The isotopic ratios are expressed as per mil $(\% 0)$ difference between the ${ }^{18} \mathrm{O} /{ }^{16} \mathrm{O}$ and ${ }^{13} \mathrm{C} /{ }^{12} \mathrm{C}$ in the samples and the laboratory standard Carrara Marble. The isotopic data in this paper are reported relative to Chicago PDB-1.

\section{RESULTS AND DISCUSSION}

\section{Hole 646B}

In Figure 2, the stable isotopic record for Hole 646B is shown as a function of depth below seafloor. A time scale based on the biostratigraphic and magnetostratigraphic data also is presented 
for comparison of previously established major stable isotopic events. All stable isotopic results are tabulated in Appendix A. A detailed stable isotopic record for the upper $\sim 85 \mathrm{~m}$ of Site 646 with approximately 20 -cm sampling interval is presented elsewhere (see Aksu et al., this volume); however, the data are tabulated in Appendix B for comparison between the isotopic variations in the Quaternary with those in the Miocene and Pliocene. Here, the isotopic data in the upper $85 \mathrm{~m}$ are plotted as "one sample per section" to maintain a consistency in the temporal resolution.

The base of Hole 646B lies within magnetochron 10 (Clement et al., this volume), at $\sim 8.5$ to $8.9 \mathrm{Ma}$. A few biostratigraphic markers at this level confirmed the upper Miocene age (Srivastava, Arthur, et al., 1987). In samples from 766 through $747 \mathrm{mbsf}$, the $\delta^{18} \mathrm{O}$ values fluctuated between 1.2 and $-1.2 \%$, with corresponding $\delta^{13} \mathrm{C}$ values of approximately $0.4 \%$ (Fig. 2). A dramatic enrichment of about $2 \% 0$ was observed in the $\delta^{18} \mathrm{O}$ values between 738.5 and 730 mbsf. A similar but lower-amplitude shift also was observed in $\delta^{13} \mathrm{C}$ values at the same boundary. This transition correlates with the right-to-left coiling change in $N$. atlantica and occurs near the upper part of magnetochron 10. A similar shift in both the $\delta^{18} \mathrm{O}$ and $\delta^{13} \mathrm{C}$ records that correlates with the coiling change in all Neogloboquadrina species also was observed at Hole 611C of DSDP Leg 94 (Keigwin et al., 1987). However, the shift at Hole $611 \mathrm{C}$ was dated to occur within magnetochron 7 . The timing of the coiling change for this taxon is not well constrained chronologically; it has been found to occur at the top of foraminifer Zone N17 of Blow (1969), at DSDP Site 407 (Poore, 1974), and near the middle of Zone N16 at DSDP Site 116 (Berggren, 1972). Lack of detailed magnetostratigraphic data in these sites precluded direct correlation of coiling change for $N$. atlantica to ODP Hole 646B.

Causes of this large shift in the $\delta^{18} \mathrm{O}$ record at $\sim 738.5-730$ mbsf are not well understood. Several possible explanations may be suggested:

1. Depleted $\delta^{18} \mathrm{O}$ values near the base of Hole 646B may represent diagenetic alteration of the $\delta^{18} \mathrm{O}$ signal by preferential dissolution and re-precipitation of calcium carbonate from pore water at relatively higher in-situ temperatures. However, microscopic examination of foraminifers in samples above and below this transition showed no conspicuous difference in test morphology and structure. Results of benthic isotopic records (in progress) may clarify the problem.

2. The observed $\sim 2 \%_{0}$ shift in the $\delta^{18} \mathrm{O}$ and $\sim 1 \% 0$ shift in the $\delta^{13} \mathrm{C}$ records may be interpreted as continental ice-growth events in the late Miocene. Several studies suggested late Miocene expansion of the Antarctic Ice Cap (Cita and Ryan, 1979; Ciesielski et al., 1982; McKenzie et al., 1984), others also proposed significant Northern Hemisphere climatic cooling and glaciation in the late Miocene (Denton and Armstrong, 1969; Mudie and Helgason, 1983; Barnosky, 1983).

3. The increase in the $\delta^{18} \mathrm{O}$ values may represent a late Miocene cooling in the surface waters in the Labrador Sea, with little or no long-term continental ice storage. There is little information about the depth habitat of $N$. atlantica, but data for other Neogloboquadrina species, such as $N$. pachyderma and $N$. dutertrei, suggest that these species may deposit their shells at near-uniform water temperature by adjusting their preferred depth habitats (Fairbanks et al., 1982). No isotopic evidence exists for a late Miocene glaciation as large as $2 \% 0$ (Elmstrom and Kennett, 1986). Similar, but lower-magnitude isotopic enrichments observed in North Atlantic sediments (Keigwin et al., 1987) suggest that at least part of this major enrichment in the isotopic data from Hole $646 \mathrm{~B}$ may be attributed to a temperature decrease in the Labrador Sea surface waters.
From about $730 \mathrm{mbsf}$ to $480 \mathrm{mbsf}$, the stable isotopic record of Hole 646B remains relatively constant, fluctuating between 0.5 and $2.5 \%$ in the $\delta^{18} \mathrm{O}$ values and -1.0 and $1.0 \%$ in the $\delta^{13} \mathrm{C}$ values (Fig. 2). An enrichment of about $2.0 \%$ was observed in both the $\delta^{18} \mathrm{O}$ and the $\delta^{13} \mathrm{C}$ values from a depth of about 480 through 435 mbsf. This transition occurred in the lower Pliocene at approximately 5.5 to $5 \mathrm{Ma}$. Similar enrichments also were observed in the benthic and planktonic isotopic records of DSDP Hole 552A. These were interpreted as short-duration (i.e., $<20,000 \mathrm{yr}$ ) glaciations at approximately 5 and $5.5 \mathrm{Ma}$. Poor core recovery in this interval, which restricted the stable isotopic data to one sample per core in Hole 646B, limited a direct correlation between the North Atlantic and the Labrador Sea.

Excellent core recovery at depths of between 405 and 265 mbsf in Hole 646B and, except for a few barren intervals, abundant foraminifers in the samples, allowed us to establish a detailed lower Pliocene stable-isotope stratigraphy. In general, the $\delta^{18} \mathrm{O}$ and $\delta^{13} \mathrm{C}$ values in samples from Cores 105-646B-43X through $105-646 \mathrm{~B}-31 \mathrm{X}$ ( $\sim 4.8$ to $3.2 \mathrm{Ma}$ ) remain relatively constant, fluctuating between 1.5 and $2.5 \%$ and -0.5 and $1.0 \%$, respectively. A progressive enrichment in both the $\delta^{18} \mathrm{O}$ and $\delta^{13} \mathrm{C}$ was observed from 480 to 465 mbsf. Between 472 and 465 mbsf in Hole $646 \mathrm{~B}$, the $\delta^{18} \mathrm{O}$ values of $N$. atlantica significantly increased over background values and reached $\sim 3.6 \%$ at 368 mbsf. This maximum $\delta^{18} \mathrm{O}$ value is much heavier than the Pleistocene interglacial values, but lighter than the glacial ones. A step-wise increase in $\delta^{18} \mathrm{O}$ values in the section and the co-variance of $\delta^{18} \mathrm{O}$ and $\delta^{13} \mathrm{C}$ records suggest a major continental icestorage event in the early Pliocene and/or a substantial cooling of surface waters in the Labrador Sea. However, the $>63-\mu \mathrm{m}$ fraction data at this interval show no evidence for ice rafting in the Labrador Sea. We hope that benthic foraminifer isotopic data (in progress) will clarify the origin of this event. Assuming a sedimentation rate of about $90 \mathrm{~m} / \mathrm{m}$.y. during the lower Pliocene at Hole 646B, this event occurred between 4.15 and 4.24 $\mathrm{Ma}$ and represented approximately $90,000 \mathrm{yr}$.

The stable isotopic record between 275 and $210 \mathrm{mbsf}$ shows a major shift of $\sim 1.5 \%$ in $\delta^{18} \mathrm{O}$ and $\sim 10 \% 0$ in $\delta^{13} \mathrm{C}$ occurring at $270 \mathrm{mbsf}$, followed by an upward progressive depletion in both $\delta^{18} \mathrm{O}$ and $\delta^{13} \mathrm{C}$. The base of this event is marked by a zone barren of foraminifers. Linear extrapolation using magnetostratigraphic and biostratigraphic data suggested that this event occurred at approximately $3.2 \mathrm{Ma}$. A similar shift of $\sim 2.0 \%$ in the $\delta^{18} \mathrm{O}$ values and a much lower-amplitude shift of $\sim 0.5 \%$ in the $\delta^{13} \mathrm{C}$ values also occurs at approximately $179 \mathrm{mbsf}$ in Hole 646B. The base of this event also is bounded by a zone barren of foraminifers. The analyses above and below this barren zone were performed on $N$. pachyderma and $N$. atlantica, respectively. The isotopic fractionation of $N$. atlantica with respect to $N$. pachyderma was calculated as -0.58 in a few samples between 385 and 435 mbsf (Appendix A), which suggests that the amplitude of the observed shift was at least $2.5 \%$. The oldest sample showing enrichment in the $\delta^{18} \mathrm{O}$ values occurred immediately above the transition Gauss and Matuyama magnetic chrons (Fig. 2; Clement et al., this volume), at approximately $2.42 \mathrm{Ma}$. Samples in Cores 105-646B-21X and 105-646B-22X were barren of foraminifers. Thus, the age of the isotopic transition could not be determined accurately. However, the $>63-\mu \mathrm{m}$ fraction data suggest that the first substantial ice rafting in the Labrador Sea started at $\sim 2.56 \mathrm{Ma}$. Similar major shifts in the benthic isotopic records were reported previously from the North Atlantic DSDP Holes 552A and 606, which reflects the beginning of glacial/interglacial cyclicity in the Northern Hemisphere (Shackleton and Hall, 1984; Keigwin, 1987).

Between 175 and 130 mbsf, poor core recovery restricted the stable isotopic data to one sample per core. Above $130 \mathrm{mbsf}$, the 


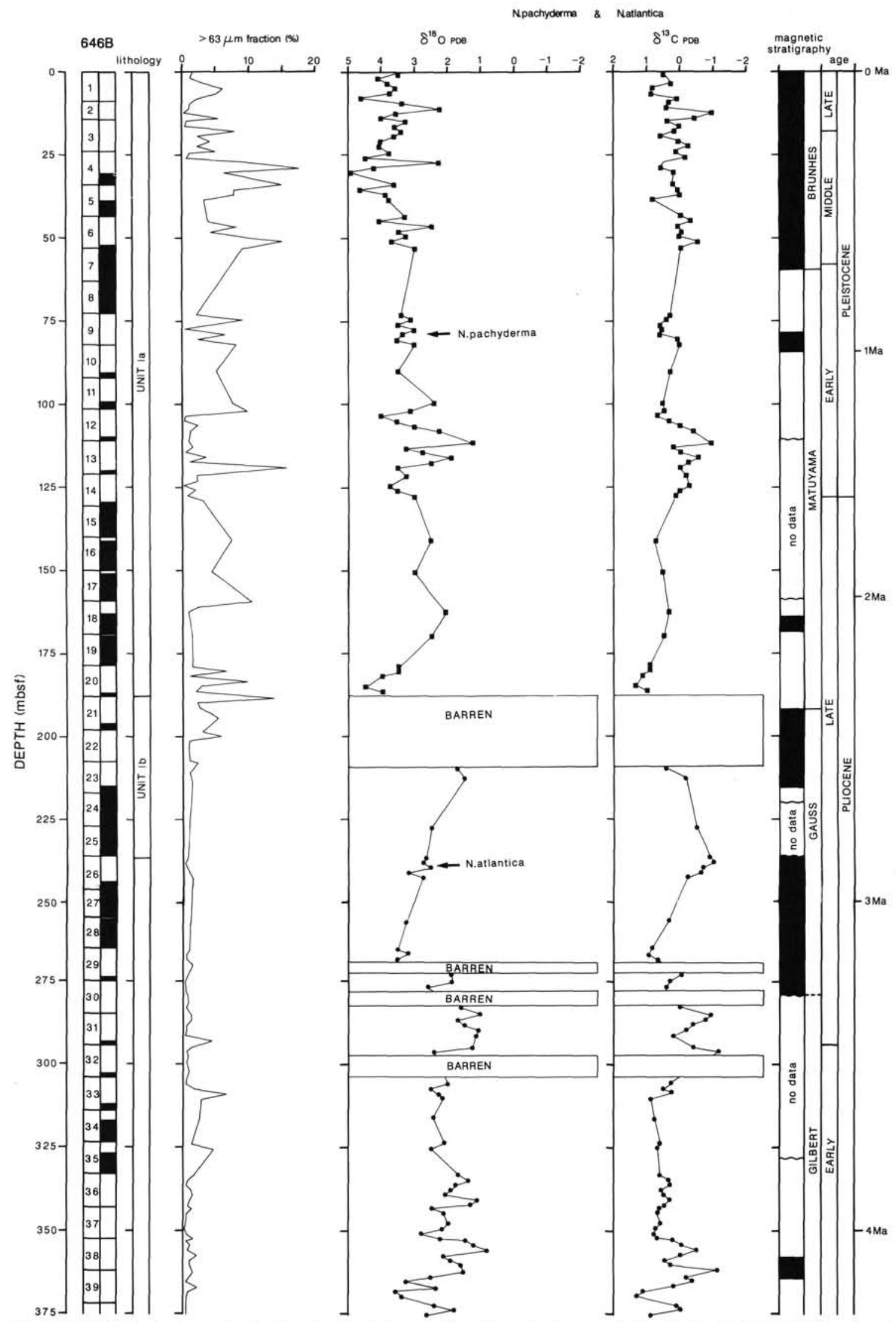

Figure 2. Stable isotopic results for the planktonic foraminifers $N$. pachyderma and $N$. atlantica (both in $>150 \mu \mathrm{m}$ ) and $>63-\mu \mathrm{m}$ fraction from Hole 646B. Magnetostratigraphic data from Clement (this volume), ages from summary biostratigraphy and magnetostratigraphy (Srivastava, Arthur, et al., 1987). 


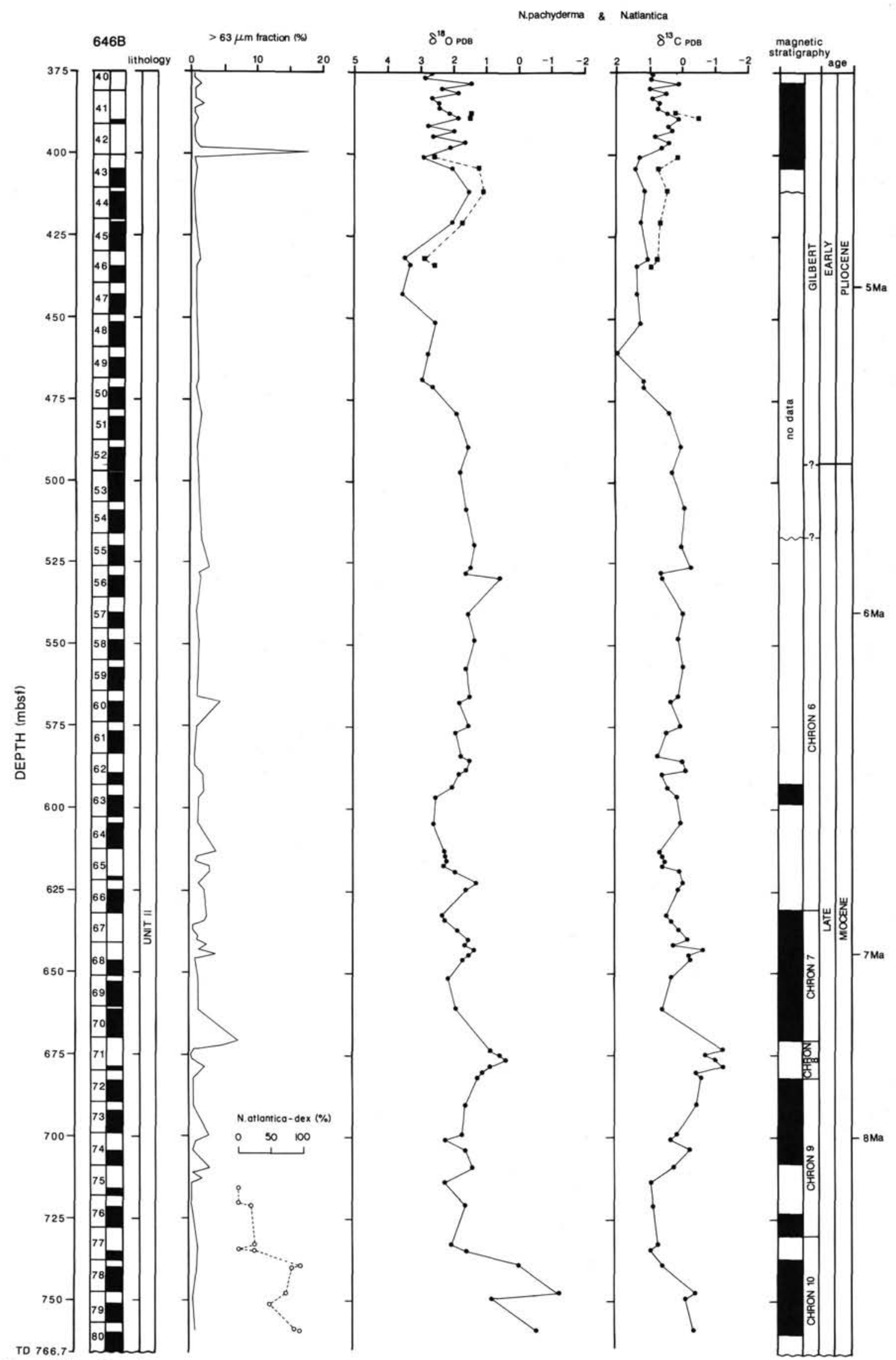

Figure 2 (continued). 
stable isotopic record shows large fluctuations; this reflects the glacial/interglacial cyclicity of the Pleistocene. At about 107 mbsf $(\sim 1.4 \mathrm{Ma})$, a large shift of about $2.8 \% 0$ in $\delta^{18} \mathrm{O}$ and $1.8 \%$ in $\delta^{13} \mathrm{C}$ was observed. This may represent a lower Pleistocene glacial/interglacial cycle similar to those reported in the highresolution stable isotopic record of DSDP Site 607 (Ruddiman et al., 1986), which was fortuitously recorded with relatively low-resolution sampling.

The isotopic record shows an overall enrichment of about $4.0 \% 0$ in $\delta^{18} \mathrm{O}$ and $1.0 \%$ in $\delta^{13} \mathrm{C}$ from the base to top of Hole 646B. In general, this enrichment probably represents the progressive climatic cooling that began in the middle and late Miocene and continued throughout the Pliocene, leading to the Pleistocene glaciations.

\section{Hole 647A}

Hole $647 \mathrm{~A}$ was drilled to a depth of $716.6 \mathrm{mbsf}$. Only the upper 165 mbsf of the drilled interval was sampled for stable isotopic analyses (Fig. 3). An unconformity that separated middle Miocene from late Pliocene was identified at $\sim 116.5$ mbsf (Srivastava, Arthur, et al., 1987). A second unconformity that separated early Miocene from late Oligocene was recognized at $\sim 135$ mbsf. Available chronostratigraphic data suggest that the Pliocene-Pleistocene section of Hole 647A was continuous.

Figure 3 shows the stable isotopic record for Hole 647A. A time scale based on biostratigraphic and magnetostratigraphic data also is presented for comparison of previously established major stable isotopic events. All stable isotopic results are tabulated in Appendix C. A detailed stable isotopic record for the upper $\sim 55 \mathrm{~m}$ of Hole $647 \mathrm{~B}$ is presented elsewhere (see Aksu et al., this volume). Here, only the isotopic data from Hole 647A are presented. Samples between 166 and 135 mbsf and 116.5 and $101 \mathrm{mbsf}$ did not contain enough foraminifers to conduct stable isotopic analyses. Samples between 135 and $116.5 \mathrm{mbsf}$ were barren of foraminifers.

The stable isotopic data for Hole 647A are similar to the upper $\sim 180 \mathrm{~m}$ of Hole $646 \mathrm{~B}$ in exhibiting large fluctuations in both the $\delta^{18} \mathrm{O}$ and the $\delta^{13} \mathrm{C}$ values. At about $64 \mathrm{mbsf}$, a dramatic shift that occurred at $\sim 1.4 \mathrm{Ma}$ could be seen in both isotopes (i.e., $3.7 \% 0$ in $\delta^{18} \mathrm{O}$ and $2.5 \% 0$ in $\delta^{13} \mathrm{C}$ ). Several duplicate analyses at this transition confirmed the validity and the amplitude of the observed shift. At present, the causes of this large shift are not well understood. No comparable isotopic event has been reported from the North Atlantic; however, a similar shift in both isotopes (with a much smaller amplitude) was observed in the stable isotopic record of Hole 646B.

\section{CONCLUSIONS}

Initial stable isotopic analyses for planktonic foraminifers $N$. pachyderma and $N$. atlantica from upper Miocene to Holocene sediments at Hole 646B and upper Pliocene to Holocene sediments at Hole 647A show the following patterns similar to those observed in the North Atlantic Ocean (i.e., Shackleton and Hall, 1984; Keigwin, 1987):

1. Both the $\delta^{18} \mathrm{O}$ and the $\delta^{13} \mathrm{C}$ values show a considerable enrichment between 2.66 and $2.42 \mathrm{Ma}$. The $\delta^{18} \mathrm{O}$ values at this interval are comparable to those recorded during the Pleistocene glacial periods. An interval barren of foraminifers situated immediately below the oldest sample showing the enrichment precludes an accurate age determination for this zone. The $>63$ $\mu \mathrm{m}$ data indicated that the initial ice rafting began as early as $2.56 \mathrm{Ma}$. This enrichment probably reflects significant longterm ice storage in the Northern Hemisphere.

2. There is also enrichment of both isotopes at about 3.2 $\mathrm{Ma}$, the $\delta^{18} \mathrm{O}$ values of which remain relatively lighter than those recorded during the Pleistocene glacial periods. However, these values are considerably heavier than those of interglacial periods. This shift in the isotopic data can be interpreted as a major continental ice-storage event in the early Pliocene and/or a substantial cooling of surface waters in the Labrador Sea. Work in progress on the benthic foraminifer isotopic record may clarify the origin of this shift.

3. A dramatic enrichment of $\delta^{18} \mathrm{O}$, associated with a much lower-amplitude shift in $\delta^{13} \mathrm{C}$, occurs in Hole 646B and correlates with the right-to-left coiling change in $N$. atlantica, near the upper part of magnetochron 10. A comparable shift was also observed at Hole 611C of DSDP Leg 94, which correlates with the coiling change in all Neogloboquadrina species. However, the shift at Hole $611 \mathrm{C}$ was dated as occurring within magnetochron 7. To date, the cause of this large shift in isotopic record and the age discrepancy is not well understood.

\section{ACKNOWLEDGMENTS}

Special thanks to the crew and scientific personnel of Leg 105. This work could not have been finished without the help of several people, and we are grateful to Sandra Hookey and Elizabeth Hearn of the Memorial University of Newfoundland (MUN) for foraminifer sample processing, Spencer Vatcher (MUN) for stable isotopic preparation and data acquisition on the mass spectrometer, and Larry Nolan (MUN) for drafting and reproduction. We thank B. Clement for providing paleomagnetic data. This research was fully supported by NSERC Grant A6896. This is Centre for Earth Resources Research contribution CERR87-7.

\section{REFERENCES}

Barnosky, C. W., 1983. Late Miocene vegetational and climatic variations inferred from a pollen record in northwest Wyoming. Science, 223:49-51.

Berggren, W. A., 1972. Cenozoic biostratigraphy and paleobiogeography of the North Atlantic. In Laughton, A. S., Berggren, W. A., et al., Init. Repts. DSDP, 12: Washington (U.S. Govt. Printing Office), 965-1001.

Blow, W. H., 1969. Late middle Eocene to Recent planktonic foraminiferal biostratigraphy. In Bronnimann, P., and Renz, H. H. (Eds.), Proc., First Planktonic Conf.: Leiden (E. J. Brill), 199-422.

Ciesielski P. F., Ledbetter, M. T., and Ellwood, B. B., 1982. The development of Antarctic glaciation and the Neogene paleoenvironment of the Maurice Ewing Bank. Mar. Geol., 46:1-51.

Cita, M. B., and Ryan, W.B.F., 1979. Late Neogene environmental evolution. In von Rad, U., Ryan, W.B.F., et al., Init. Repts. DSDP, 47(Pt. 1): Washington (U.S. Govt. Printing Office), 447-459.

Denton, G. H., and Armstrong, R. L., 1969. Miocene-Pliocene glaciations in southern Alaska. Am. J. Sci., 267:1121-1142.

Elmstom, K. M., and Kennett, J. P., 1986. Late Neogene paleoceanographic evolution of Site 590: Southwest Pacific. In Kennett, J. P., von der Borch, C. C., et al., Init. Repts. DSDP, 90 (Pt. 2): Washington (U.S. Govt. Printing Office), 1361-1381.

Fairbanks, R. G., Sverdlove, M., Free, R., Wiebe, P. H., and Bé, A.W.H., 1982. Vertical distribution and isotopic fractionation of living planktonic foraminifera from the Panama Basin. Nature, 289: 841-844.

Keigwin, L. D., 1987. Pliocene stable-isotope record of Deep Sea Drilling Project Site 606: sequential events of ${ }^{18} \mathrm{O}$ enrichment beginning at 3.1 Ma. In Ruddiman, W. F., Kidd, R. B., Thomas, E., et al., Init. Repts. DSDP, 94: Washington (U.S. Govt. Printing Office), 911-920.

Keigwin, L. D., Aubry, M.-P., and Kent, D. V., 1987. North Atlantic late Miocene stable-isotope stratigraphy, biostratigraphy, and magnetostratigraphy. In Ruddiman, W. F., Kidd, R. B., and Thomas, E., et al., Init. Repts. DSDP, 94: Washington (U.S. Govt. Printing Office), 935-963.

McKenzie, J. A., Weissert, H. J., Poore, R. Z., Wright, R. C., Percival, S. F., Jr, Oberhäusli, H., and Casey, M., 1984. Paleoceanographic implications of stable-isotope data from upper Miocene-lower Pliocene sediments from the southeast Atlantic (Deep Sea Drilling Program Site 519). In Hsü, K. J., LaBrecque, J. L., et al., Init. Repts. DSDP, 73: Washington (U.S. Govt. Printing Office), 717-784.

Mudie, P. J., and Helgason, J., 1983. Palynological evidence for Miocene climatic cooling in eastern Iceland about 9.8 Ma. Nature, 303: 689-692. 
Poore, R. Z., 1979. Oligocene through Quaternary planktonic foraminiferal biostratigraphy of the North Atlantic: DSDP Leg 42. In Luyendyk, B. P., Cann, J. R., et al., Init. Repts. DSDP, 49: Washington (U.S. Govt. Printing Office), 447-518.

Ruddiman, W. F., Raymo, M., and McIntyre, A., 1986. Matuyama 41,000-year cycles: North Atlantic Ocean and Northern Hemisphere ice sheets. Earth Planet. Sci. Lett., 80:117-129.

Shackleton, N. J., and Opdyke, N. D., 1977. Oxygen isotope and paleomagnetic evidence for early Northern Hemisphere glaciation. $\mathrm{Na}$ ture, 270:216-219.

Shackleton, N. J., and Hall, M. A., 1984. Oxygen and carbon isotope stratigraphy of Deep Sea Drilling Project Hole 552A: Plio-Pleistocene glacial history. In Roberts, D. G., Schnitker, D., et al., Init.
Repts. DSDP, 81: Washington (U.S. Govt. Printing Office), 599609.

Shackleton, N. J., Backman, J., Zimmerman, H., Kent, D. V., Hall, M. A., et al., 1984. Oxygen isotope calibration of the onset of ice-rafting and history of glaciation in the North Atlantic region. Nature, 307:620-623.

Srivastava, S. P., Arthur, M., et al., 1987. Proc. ODP, Init. Repts., 105: College Station, TX (Ocean Drilling Program).

Date of initial receipt: 20 July 1987 Date of acceptance: 20 November 1987 Ms 105B:139 


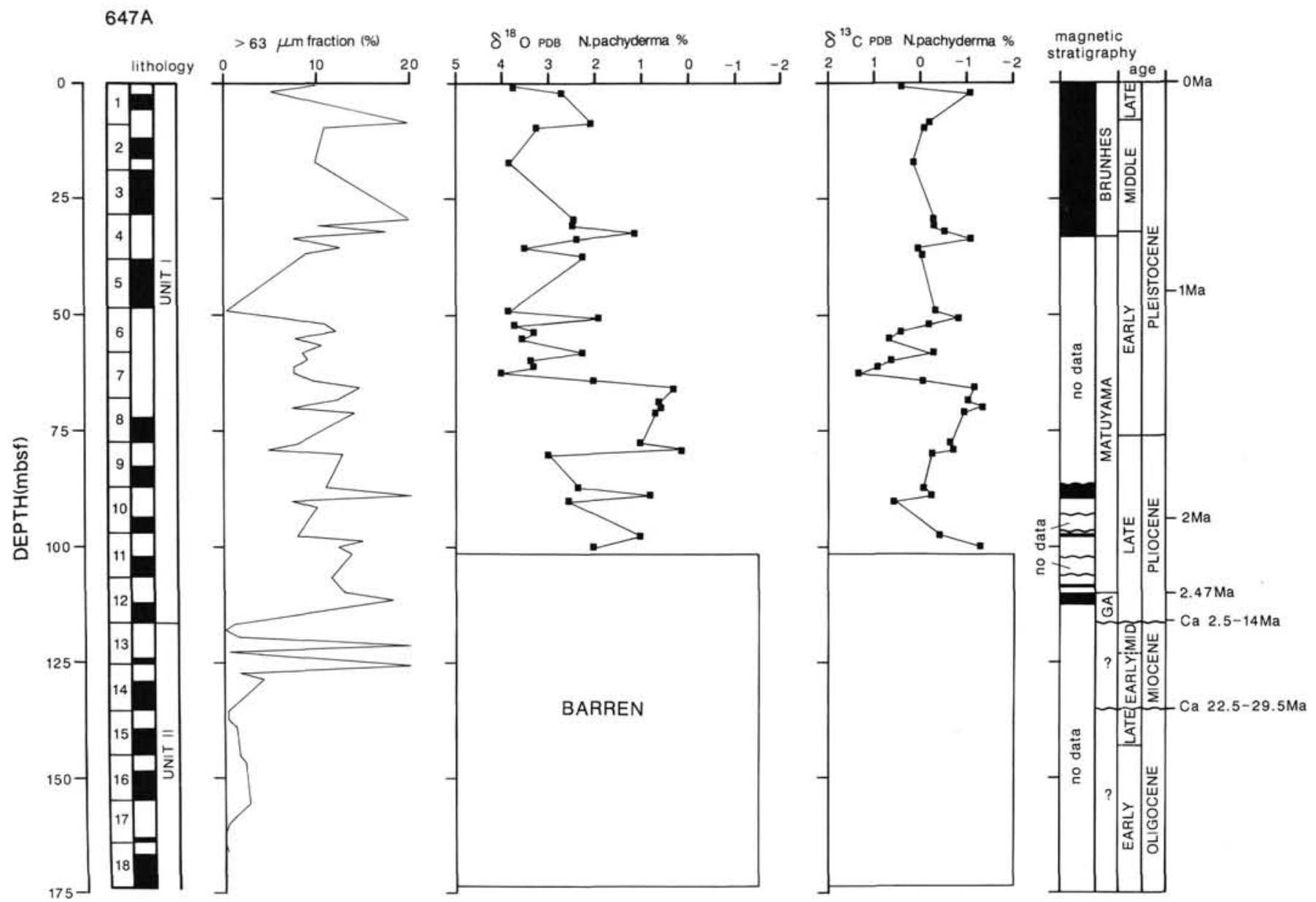

Figure 3. Stable isotopic results for the planktonic foraminifer $N$. pachyderma $(>150 \mu \mathrm{m})$ and $>63-\mu \mathrm{m}$ fraction from Hole $647 \mathrm{~A}$. Magnetostratigraphic data from Clement et al. (this volume); ages from summary biostratigraphy and magnetostratigraphy (Srivastava, Arthur, et al., 1987). 
APPENDIX A

Oxygen and carbon isotopic data for $N$. pachyderma $(\mathrm{P})$ and $N$. atlantica (A) sinistral and $>63-\mu \mathrm{m}$ data for Hole $646 \mathrm{~B}$.

\begin{tabular}{|c|c|c|c|c|}
\hline $\begin{array}{l}\text { Depth } \\
\text { (mbsf) }\end{array}$ & $\begin{array}{c}>63 \mu \mathrm{m} \\
(8)\end{array}$ & $\begin{array}{c}\delta^{18} 0 \\
\left({ }^{\circ} / 00\right)\end{array}$ & $\begin{array}{l}\delta^{13} \mathrm{C} \\
\left({ }^{\circ} /{ }^{\circ}\right)\end{array}$ & \\
\hline $0.39-0.41$ & 1.63 & 3.50 & 0.51 & $\overline{\mathrm{P}}$ \\
\hline $2.01-2.03$ & 1.34 & 4.09 & 0.36 & $P$ \\
\hline $3.40-3.42$ & 3.33 & 3.82 & 0.27 & $\mathbf{P}$ \\
\hline $5.00-5.02$ & 6.02 & 3.61 & 0.85 & $P$ \\
\hline $6.60-6.62$ & 5.18 & 3.76 & 0.89 & P \\
\hline $8.01-8.03$ & 2.33 & 4.63 & 0.08 & $P$ \\
\hline $9.40-9.42$ & 1.33 & 3.37 & 0.35 & P \\
\hline $11.10-11.11$ & 1.08 & 2.23 & 0.44 & P \\
\hline $12.40-12.42$ & 0.36 & 3.55 & -0.96 & P \\
\hline $14.15-14.17$ & 5.52 & 4.02 & -0.41 & P \\
\hline $14.80-14.82$ & 0.62 & 3.25 & 0.42 & P \\
\hline $16.39-16.41$ & 0.31 & 3.62 & 0.03 & $\mathrm{P}$ \\
\hline $17.90-17.92$ & 7.75 & 3.43 & 0.16 & $\mathbf{P}$ \\
\hline $19.39-19.41$ & 1.97 & 3.63 & 0.62 & $\mathbf{P}$ \\
\hline $20.91-20.93$ & 3.92 & 4.01 & 0.07 & P \\
\hline $22.30-22.32$ & 2.29 & 4.05 & -0.25 & $\mathrm{P}$ \\
\hline $23.70-23.72$ & 5.03 & 3.86 & 0.16 & $P$ \\
\hline $24.57-24.59$ & 1.17 & 3.75 & 0.11 & $\mathrm{P}$ \\
\hline $26.19-26.21$ & 0.48 & 4.50 & -0.17 & $\mathrm{P}$ \\
\hline $27.49-27.51$ & 10.63 & 2.25 & 0.51 & $\mathrm{P}$ \\
\hline $29.19-29.21$ & 17.63 & 4.28 & 0.62 & $P$ \\
\hline $30.26-30.28$ & 6.19 & 4.96 & 0.19 & $\mathrm{P}$ \\
\hline $33.83-33.87$ & 17.39 & 3.58 & 0.26 & $\mathrm{P}$ \\
\hline $35.30-35.34$ & 7.83 & 4.65 & 0.07 & $\mathrm{P}$ \\
\hline $36.80-36.84$ & 7.80 & 3.87 & 0.01 & $\mathbf{P}$ \\
\hline $38.36-36.40$ & 3.23 & 3.79 & 0.88 & $\mathrm{P}$ \\
\hline $43.52-43.56$ & 3.85 & 3.27 & -0.04 & $\mathrm{P}$ \\
\hline $44.90-44.94$ & 4.09 & 4.07 & -0.35 & $\mathrm{P}$ \\
\hline $46.40-46.44$ & 8.20 & 2.45 & 0.06 & $\mathrm{P}$ \\
\hline $47.90-47.94$ & 4.06 & 3.50 & -0.07 & $\mathrm{P}$ \\
\hline $49.40-49.44$ & 9.18 & 3.25 & 0.06 & $\mathrm{P}$ \\
\hline $51.00-51.04$ & 15.41 & 3.72 & -0.53 & P \\
\hline $52.30-52.34$ & 9.25 & 3.01 & 0.02 & $P$ \\
\hline $73.00-73.04$ & 1.89 & 3.39 & 0.29 & $\mathrm{P}$ \\
\hline $74.30-74.34$ & 9.13 & 3.16 & 0.41 & $\mathrm{P}$ \\
\hline $76.00-76.04$ & 5.06 & 3.51 & 0.32 & $\mathrm{P}$ \\
\hline $77.30-77.34$ & 0.66 & 2.98 & 0.53 & $\mathrm{P}$ \\
\hline $78.61-78.65$ & 6.49 & 3.43 & 0.59 & $\mathrm{P}$ \\
\hline $80.10-80.14$ & 2.49 & 3.56 & 0.06 & $\mathrm{P}$ \\
\hline $81.60-81.64$ & 7.94 & 3.01 & 0.02 & $\mathrm{P}$ \\
\hline $90.40-90.44$ & 5.06 & 3.51 & 0.26 & $\mathrm{P}$ \\
\hline $98.70-98.74$ & 7.50 & 2.41 & 0.53 & $\mathrm{P}$ \\
\hline $102.15-102.20$ & 9.82 & 3.13 & 0.47 & $\mathrm{P}$ \\
\hline $103.65-103.70$ & 0.19 & 4.01 & 0.69 & $\mathrm{P}$ \\
\hline $105.15-105.20$ & 0.36 & 3.52 & 0.33 & $\mathrm{P}$ \\
\hline $106.65-106.70$ & 2.36 & 3.03 & 0.00 & $\mathrm{P}$ \\
\hline $108.15-108.20$ & 1.28 & 2.25 & -0.39 & $\mathbf{P}$ \\
\hline $111.30-111.35$ & 1.08 & 1.37 & -0.98 & $\mathrm{P}$ \\
\hline $112.80-112.85$ & 1.40 & 3.26 & 0.20 & $\mathbf{P}$ \\
\hline $114.30-114.35$ & 0.46 & 2.76 & 0.00 & $\mathrm{P}$ \\
\hline $115.20-115.25$ & 3.56 & 1.91 & -0.58 & $\mathrm{P}$ \\
\hline $117.30-117.35$ & 0.95 & 2.49 & -0.25 & $\mathrm{P}$ \\
\hline $118.80-118.85$ & 15.72 & 3.51 & -0.02 & $\mathrm{P}$ \\
\hline $121.15-121.20$ & 2.37 & 3.24 & -0.19 & $\mathrm{P}$ \\
\hline $122.65-122.70$ & 2.34 & & & \\
\hline $124.15-124.20$ & 0.09 & 3.76 & -0.28 & $\mathrm{P}$ \\
\hline $125.65-125.70$ & 2.15 & 3.52 & 0.00 & $\mathrm{P}$ \\
\hline
\end{tabular}

\begin{tabular}{|c|c|c|c|c|}
\hline $\begin{array}{l}\text { Depth } \\
\text { (mbsf) }\end{array}$ & $\begin{array}{c}>63 \mu \mathrm{m} \\
(8)\end{array}$ & $\begin{array}{l}\delta^{18} 0 \\
\left({ }^{\circ} / \circ 0\right)\end{array}$ & $\begin{array}{l}\delta^{13} \mathrm{C} \\
\left({ }^{\circ} /{ }^{\circ}\right)\end{array}$ & \\
\hline $127.15-127.20$ & 0.77 & 3.01 & 0.13 & $P$ \\
\hline $128.65-128.70$ & 2.95 & & & \\
\hline $141.10-141.15$ & 7.51 & 2.52 & 0.75 & $\mathbf{P}$ \\
\hline $150.90-150.95$ & 4.35 & 3.02 & 0.51 & $P$ \\
\hline $159.50-159.55$ & 10.37 & & & \\
\hline $160.88-160.93$ & 2.55 & & & \\
\hline $162.38-162.43$ & 1.24 & 2.07 & 0.36 & $\mathrm{P}$ \\
\hline $178.77-178.82$ & 1.60 & 3.51 & 0.92 & $P$ \\
\hline $180.27-180.32$ & 6.55 & 3.48 & 0.90 & $\mathrm{P}$ \\
\hline $181.77-181.82$ & 1.29 & 3.98 & 1.15 & $P$ \\
\hline $183.27-183.32$ & 9.72 & & & \\
\hline $184.77-184.82$ & 2.77 & 4.49 & 1.38 & $P$ \\
\hline $186.27-186.32$ & 1.94 & 3.96 & 1.01 & $\mathrm{P}$ \\
\hline $188.37-188.42$ & 13.78 & & & \\
\hline $189.87-189.92$ & 2.24 & & & \\
\hline $191.37-191.42$ & 2.62 & & & \\
\hline $192.87-192.92$ & 4.36 & & & \\
\hline $194.37-194.42$ & 5.31 & & & \\
\hline $198.45-198.50$ & 3.07 & & & \\
\hline $199.94-199.99$ & 5.81 & & & \\
\hline $201.45-201.50$ & 1.14 & & & \\
\hline $202.94-202.99$ & 1.04 & & & \\
\hline $205.94-205.99$ & 1.14 & & & \\
\hline $206.85-206.90$ & 1.00 & & & \\
\hline $207.85-207.90$ & 2.27 & & & \\
\hline $209.35-209.40$ & 1.85 & 1.72 & 0.43 & A \\
\hline $210.85-210.90$ & 1.12 & & & \\
\hline $212.34-212.39$ & 1.22 & 1.48 & -0.21 & A \\
\hline $213.84-213.89$ & 1.21 & & & \\
\hline $226.70-226.75$ & 1.00 & 2.50 & -0.50 & A \\
\hline $236.49-236.54$ & 0.72 & 2.65 & -0.92 & A \\
\hline $237.99-238.04$ & 0.50 & 2.72 & -1.05 & A \\
\hline $239.49-239.54$ & 0.73 & 2.52 & -0.72 & A \\
\hline $240.99-241.04$ & 0.94 & 3.21 & -0.63 & A \\
\hline $242.49-242.54$ & 1.51 & 2.74 & -0.21 & A \\
\hline $256.30-256.35$ & 1.25 & 3.25 & 0.34 & A \\
\hline $265.70-265.75$ & 1.10 & 3.50 & 1.02 & A \\
\hline $267.20-267.25$ & 0.51 & 3.23 & 0.99 & A \\
\hline $268.70-268.75$ & 0.49 & 3.52 & 0.65 & A \\
\hline $270.20-270.25$ & 1.55 & & & \\
\hline $271.70-271.75$ & 1.24 & & & \\
\hline $273.20-273.25$ & 0.85 & 1.89 & -0.05 & A \\
\hline $275.39-275.44$ & 0.33 & 1.90 & 0.33 & A \\
\hline $276.89-276.94$ & 0.46 & 2.63 & 0.39 & A \\
\hline $278.39-278.44$ & 0.35 & & & \\
\hline $279.89-279.94$ & 0.69 & & & \\
\hline $281.39-281.44$ & 0.81 & & & \\
\hline $282.89-282.94$ & 0.42 & 1.64 & 0.03 & A \\
\hline $284.97-285.02$ & 1.30 & 1.05 & -0.94 & A \\
\hline $286.47-286.52$ & 1.21 & 1.71 & -0.78 & A \\
\hline $287.97-288.02$ & 0.67 & 1.50 & -0.65 & A \\
\hline $289.47-289.52$ & 0.67 & 1.12 & -0.17 & A \\
\hline $290.97-291.02$ & 0.37 & 1.16 & 0.20 & A \\
\hline $292.47-292.52$ & 4.29 & & & \\
\hline $294.58-294.63$ & 1.19 & 1.26 & -0.40 & A \\
\hline $296.08-296.13$ & 0.66 & 2.42 & -1.14 & A \\
\hline $297.58-297.63$ & 0.88 & & & \\
\hline
\end{tabular}




\begin{tabular}{|c|c|c|c|c|}
\hline $\begin{array}{l}\text { Depth } \\
\text { (mbsf) }\end{array}$ & $\begin{array}{c}>63 \mu \mathrm{m} \\
(8)\end{array}$ & $\begin{array}{c}\delta^{18} 0 \\
(\% / 00)\end{array}$ & $\begin{array}{l}\delta^{13} \mathrm{C} \\
\left({ }^{\circ} / 0^{\circ}\right)\end{array}$ & \\
\hline $299.08-299.13$ & 0.68 & & & \\
\hline $300.58-300.63$ & 0.78 & & & \\
\hline $302.08-302.13$ & 0.94 & & & \\
\hline $304.35-304.40$ & 0.66 & & & \\
\hline $305.85-305.90$ & 0.41 & 2.01 & 0.25 & A \\
\hline $307.35-307.40$ & 1.85 & 2.50 & 0.52 & A \\
\hline $308.85-308.90$ & 6.40 & 2.27 & 0.24 & A \\
\hline $310.35-310.40$ & 1.05 & 2.15 & 0.91 & A \\
\hline $316.80-316.85$ & 2.50 & 2.45 & 0.79 & A \\
\hline $323.62-323.67$ & 1.38 & 2.11 & 0.63 & A \\
\hline $325.13-325.18$ & 4.44 & 2.49 & 0.70 & A \\
\hline $333.92-333.97$ & 1.66 & 1.68 & 0.63 & A \\
\hline $335.31-335.36$ & 0.80 & 1.34 & 0.37 & A \\
\hline $336.18-336.23$ & 0.67 & 1.76 & 0.32 & A \\
\hline $338.13-338.18$ & 1.33 & 1.88 & 0.68 & A \\
\hline $339.18-339.23$ & 1.55 & 2.05 & 0.50 & A \\
\hline $341.74-341.79$ & 0.99 & 1.07 & 0.34 & A \\
\hline $342.16-342.21$ & 0.78 & 1.37 & 0.50 & A \\
\hline $343.10-343.15$ & 1.22 & 2.45 & 0.63 & A \\
\hline $344.60-344.65$ & 0.47 & 2.13 & 0.70 & A \\
\hline $346.10-346.15$ & 0.51 & & & \\
\hline $347.60-347.65$ & 0.43 & 2.03 & 0.57 & A \\
\hline $349.10-349.15$ & 0.32 & 2.17 & 0.75 & A \\
\hline $350.60-350.65$ & 0.61 & 2.80 & 0.79 & A \\
\hline $352.10-352.15$ & 1.53 & 2.26 & 0.69 & A \\
\hline $352.98-353.03$ & 0.60 & 1.45 & 0.23 & A \\
\hline $354.48-354.53$ & 1.05 & 1.22 & -0.06 & A \\
\hline $355.93-355.98$ & 0.44 & 0.81 & -0.51 & A \\
\hline $357.48-357.53$ & 1.98 & 2.18 & 0.07 & A \\
\hline $358.97-359.02$ & 0.96 & 1.93 & 0.47 & A \\
\hline $360.45-360.50$ & 0.96 & 1.59 & 0.29 & A \\
\hline $362.19-362.24$ & 1.60 & 1.51 & -1.12 & A \\
\hline $363.69-363.74$ & 1.02 & 2.50 & -0.21 & A \\
\hline $365.19-365.24$ & 0.44 & 3.29 & -0.39 & A \\
\hline $366.69-366.74$ & 2.09 & 2.40 & 0.22 & A \\
\hline $368.19-368.24$ & 0.86 & 3.58 & 1.12 & A \\
\hline $369.69-369.74$ & 0.80 & 3.41 & 1.34 & A \\
\hline $371.91-371.96$ & 0.61 & 2.40 & 0.14 & A \\
\hline $373.41-373.46$ & 0.58 & 1.83 & -0.03 & A \\
\hline $374.91-374.96$ & 0.42 & 2.66 & 0.88 & A \\
\hline $376.41-376.46$ & 0.63 & 2.88 & 0.96 & A \\
\hline $377.91-377.96$ & 1.42 & 1.42 & 0.09 & A \\
\hline $379.41-379.46$ & 1.00 & 2.31 & 0.96 & A \\
\hline $380.87-380.92$ & 0.76 & 1.79 & 0.45 & A \\
\hline $383.06-383.11$ & 0.69 & 2.59 & 0.88 & A \\
\hline $384.57-384.62$ & 2.07 & 2.43 & 0.67 & A \\
\hline $386.07-386.12$ & 0.63 & 2.41 & 0.72 & A \\
\hline \multirow[t]{2}{*}{$387.57-387.62$} & 0.40 & 2.08 & 0.44 & A \\
\hline & & 1.42 & 0.23 & $\mathrm{P}$ \\
\hline \multirow[t]{2}{*}{$389.07-389.12$} & 1.00 & 1.84 & 0.10 & A \\
\hline & & 1.44 & -0.53 & $\mathrm{P}$ \\
\hline $391.16-391.21$ & 0.44 & 2.73 & 0.38 & A \\
\hline $392.59-392.64$ & 0.60 & 1.93 & 0.30 & A \\
\hline $394.09-394.14$ & 0.57 & 2.59 & 0.83 & A \\
\hline $395.59-395.64$ & 0.79 & 1.61 & 0.39 & A \\
\hline $397.09-397.14$ & 1.35 & 2.06 & 0.63 & \\
\hline $398.67-398.72$ & 18.11 & 2.75 & 0.92 & \\
\hline \multirow[t]{2}{*}{$401.81-401.86$} & 0.63 & 2.90 & 1.28 & A \\
\hline & & 2.55 & 0.12 & $\mathrm{P}$ \\
\hline
\end{tabular}

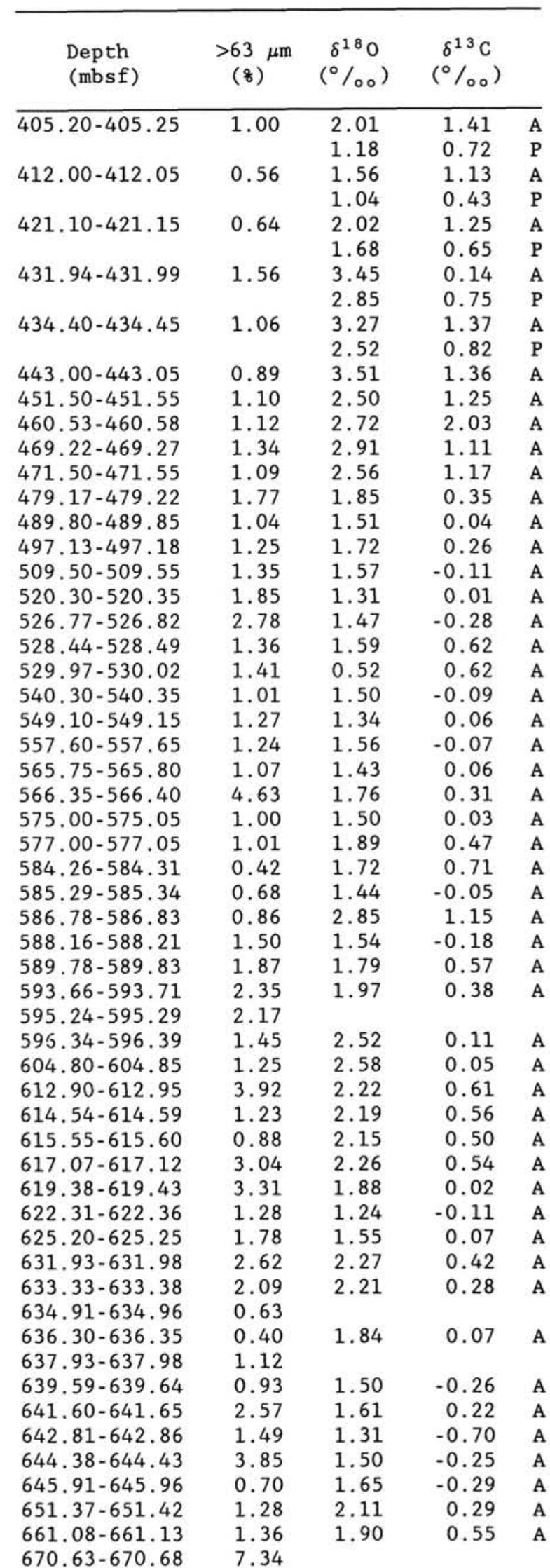


Appendix A (continued)

\begin{tabular}{ccccc}
\hline $\begin{array}{l}\text { Depth } \\
\text { (mbsf) }\end{array}$ & $\begin{array}{c}>63 \mu \mathrm{m} \\
(8)\end{array}$ & $\begin{array}{c}\left.\delta^{18} \mathrm{O}\right) \\
(\% \circ \mathrm{o})\end{array}$ & $\begin{array}{c}\delta^{13} \mathrm{C} \\
(\% / 00)\end{array}$ & \\
\hline $672.13-672.18$ & 5.44 & & & \\
$673.63-673.68$ & 0.56 & 0.83 & -1.30 & $\mathrm{~A}$ \\
$675.21-675.26$ & 0.20 & 0.53 & -0.74 & $\mathrm{~A}$ \\
$676.50-676.55$ & 0.56 & 0.36 & -1.09 & $\mathrm{~A}$ \\
$677.81-677.86$ & 2.30 & 0.82 & -1.35 & $\mathrm{~A}$ \\
$680.10-680.15$ & 1.23 & 1.07 & -0.47 & $\mathrm{~A}$ \\
$681.57-681.62$ & 0.57 & 1.20 & -0.67 & $\mathrm{~A}$ \\
$691.13-690.18$ & 0.58 & 1.64 & -0.49 & $\mathrm{~A}$ \\
$699.45-699.50$ & 2.93 & 1.70 & 0.11 & $\mathrm{~A}$ \\
$700.70-700.75$ & 0.98 & 2.20 & 0.34 & $\mathrm{~A}$ \\
$703.51-703.56$ & 0.58 & 1.56 & -0.31 & $\mathrm{~A}$
\end{tabular}

\begin{tabular}{ccccc}
\hline $\begin{array}{l}\text { Depth } \\
\text { (mbsf) }\end{array}$ & $\begin{array}{c}>63 \mu \mathrm{m} \\
(8)\end{array}$ & $\begin{array}{c}\left.\delta^{18} \mathrm{O}\right) \\
(\% / \%)\end{array}$ & $\begin{array}{c}\delta^{13} \mathrm{C} \\
\left.(\% / \%)^{\circ}\right)\end{array}$ & \\
\hline $709.12-709.17$ & 3.01 & 1.36 & 0.22 & $\mathrm{~A}$ \\
$710.27-710.32$ & 0.52 & & & \\
$711.76-711.81$ & 2.01 & & & \\
$713.76-713.81$ & 0.39 & 2.21 & 0.91 & $\mathrm{~A}$ \\
$718.31-718.36$ & 0.30 & 1.60 & 0.83 & $\mathrm{~A}$ \\
$733.08-733.13$ & 1.14 & 2.01 & 0.72 & $\mathrm{~A}$ \\
$734.80-734.85$ & 1.16 & 1.56 & 0.95 & $\mathrm{~A}$ \\
$739.90-739.95$ & 1.23 & -0.07 & 0.57 & $\mathrm{~A}$ \\
$747.54-747.59$ & 0.57 & -1.31 & -0.46 & $\mathrm{~A}$ \\
$749.09-747.14$ & 0.90 & 0.78 & -0.15 & $\mathrm{~A}$ \\
$758.65-758.70$ & 1.08 & -0.57 & -0.35 & $\mathrm{~A}$
\end{tabular}




\begin{tabular}{|c|c|c|c|}
\hline $\begin{array}{l}\text { Depth } \\
\text { (mbsf) }\end{array}$ & $\begin{array}{c}>63 \mu \mathrm{m} \\
(8)\end{array}$ & $\begin{array}{c}\delta^{18} 0 \\
\left({ }^{\circ} / 00\right)\end{array}$ & $\begin{array}{l}\delta^{13} \mathrm{C} \\
\left({ }^{\circ} /{ }^{\circ}\right)\end{array}$ \\
\hline 0.00 & 1.80 & 0.55 & 2.24 \\
\hline 0.20 & 1.60 & 0.56 & 2.13 \\
\hline 0.40 & 1.00 & 0.75 & 2.49 \\
\hline 0.60 & 1.23 & 0.47 & 2.01 \\
\hline 0.80 & 0.79 & 0.55 & 2.59 \\
\hline 1.00 & 0.85 & 0.40 & 1.80 \\
\hline 1.20 & 1.23 & -0.75 & 2.40 \\
\hline 1.45 & 0.70 & -0.04 & 2.70 \\
\hline 1.60 & 4.43 & -0.13 & 3.32 \\
\hline 1.95 & 7.40 & -0.05 & 4.30 \\
\hline 2.15 & 7.00 & -0.18 & 3.55 \\
\hline 2.30 & 2.12 & -0.15 & 3.95 \\
\hline 2.50 & 5.24 & 0.04 & 4.42 \\
\hline 2.70 & 6.42 & 0.30 & 4.15 \\
\hline 2.95 & 2.22 & 0.20 & 4.08 \\
\hline 3.15 & 10.00 & 0.05 & 3.93 \\
\hline 3.40 & 5.00 & 0.29 & 3.45 \\
\hline 3.55 & 4.00 & 0.38 & 3.60 \\
\hline 3.75 & 2.20 & 0.40 & 3.72 \\
\hline 4.00 & 3.27 & 0.43 & 3.75 \\
\hline 4.20 & 1.24 & 0.47 & 3.65 \\
\hline 4.30 & 1.89 & 0.45 & 3.70 \\
\hline 4.48 & 2.25 & 0.25 & 3.45 \\
\hline 4.70 & 4.00 & 0.40 & 3.67 \\
\hline 4.90 & 4.15 & 0.35 & 3.77 \\
\hline 5.14 & 15.00 & 0.25 & 3.41 \\
\hline 5.35 & 0.84 & 0.76 & 3.32 \\
\hline 5.60 & 5.89 & 0.70 & 3.40 \\
\hline 5.75 & 2.88 & 0.78 & 3.72 \\
\hline 5.95 & 0.68 & 0.77 & 3.68 \\
\hline 6.17 & 4.98 & 0.90 & 3.75 \\
\hline 6.38 & 3.00 & 1.35 & 3.82 \\
\hline 6.55 & 3.58 & 0.70 & 3.40 \\
\hline 6.75 & 2.25 & 0.26 & 3.55 \\
\hline 6.95 & 1.62 & -0.21 & 3.45 \\
\hline 7.12 & 0.99 & 0.04 & 4.04 \\
\hline 7.32 & 1.30 & 0.00 & 3.41 \\
\hline 7.53 & 2.25 & 0.10 & 4.60 \\
\hline 7.71 & 3.47 & 0.29 & 3.46 \\
\hline 7.90 & 7.20 & 0.17 & 3.49 \\
\hline 8.10 & 4.91 & -0.16 & 3.39 \\
\hline 8.32 & 4.89 & 0.26 & 3.41 \\
\hline 8.50 & 2.60 & 0.29 & 3.57 \\
\hline 8.55 & 1.30 & 0.30 & 3.31 \\
\hline 8.71 & 2.00 & 0.32 & 2.93 \\
\hline 8.92 & 1.90 & 0.56 & 2.86 \\
\hline 9.20 & 4.88 & 0.50 & 2.38 \\
\hline 9.40 & 1.58 & 0.18 & 2.98 \\
\hline 9.60 & 1.50 & 0.45 & 2.28 \\
\hline 9.80 & 2.80 & 0.21 & 2.08 \\
\hline 10.01 & 1.12 & 0.35 & 2.03 \\
\hline 10.21 & 0.68 & 0.56 & 2.29 \\
\hline 10.40 & 0.35 & 0.20 & 2.44 \\
\hline 10.54 & 0.28 & -1.31 & 2.57 \\
\hline 10.72 & 0.38 & -1.00 & 1.90 \\
\hline 10.91 & 0.35 & -1.00 & 3.51 \\
\hline 11.12 & 0.99 & -0.80 & 3.57 \\
\hline
\end{tabular}

\begin{tabular}{|c|c|c|c|}
\hline $\begin{array}{l}\text { Depth } \\
\text { (mbsf) }\end{array}$ & $\begin{array}{c}>63 \mu \mathrm{m} \\
(8)\end{array}$ & $\begin{array}{l}\delta^{18} 0 \\
(\% / 00)\end{array}$ & $\begin{array}{l}\delta^{13} \mathrm{C} \\
\left({ }^{\circ} /{ }^{\circ}\right)\end{array}$ \\
\hline 11.32 & 1.20 & -0.62 & 3.97 \\
\hline 11.51 & 9.52 & -0.08 & 2.87 \\
\hline 11.72 & 9.50 & 0.09 & 4.49 \\
\hline 11.91 & 6.35 & 0.06 & 4.44 \\
\hline 12.10 & 9.29 & -1.01 & 4.34 \\
\hline 12.30 & 4.62 & -0.29 & 4.77 \\
\hline 12.51 & 0.23 & -0.18 & 4.26 \\
\hline 12.67 & 5.45 & -0.41 & 3.99 \\
\hline 12.80 & 12.02 & -0.26 & 4.09 \\
\hline 13.00 & 6.93 & -0.10 & 4.24 \\
\hline 13.15 & 2.84 & 0.05 & 4.14 \\
\hline 13.30 & 6.89 & 0.00 & 4.09 \\
\hline 13.45 & 14.62 & 0.07 & 4.38 \\
\hline 13.63 & 4.03 & 0.10 & 4.08 \\
\hline 13.85 & 6.31 & -0.06 & 4.19 \\
\hline 14.10 & 3.79 & -0.03 & 4.18 \\
\hline 14.30 & 5.39 & 0.02 & 4.19 \\
\hline 14.50 & 3.73 & 0.12 & 3.85 \\
\hline 14.67 & 1.09 & 0.25 & 3.57 \\
\hline 14.80 & 6.49 & 0.43 & 3.55 \\
\hline 14.95 & 7.50 & 0.48 & 3.45 \\
\hline 15.10 & 1.99 & 0.43 & 3.15 \\
\hline 15.33 & 0.34 & 0.42 & 3.19 \\
\hline 15.60 & 4.62 & 0.41 & 3.08 \\
\hline 15.80 & 2.79 & 0.37 & 3.74 \\
\hline 15.99 & 1.23 & 0.37 & 3.91 \\
\hline 16.15 & 0.81 & 0.36 & 3.92 \\
\hline 16.30 & 2.29 & 0.34 & 4.05 \\
\hline 16.42 & 0.41 & 0.35 & 3.67 \\
\hline 16.60 & 2.95 & 0.33 & 2.43 \\
\hline 16.78 & 0.42 & 0.42 & 2.89 \\
\hline 17.02 & 2.49 & 0.32 & 2.74 \\
\hline 17.30 & 2.32 & 0.22 & 2.57 \\
\hline 17.77 & 0.83 & 0.34 & 2.89 \\
\hline 17.97 & 0.49 & 0.11 & 2.86 \\
\hline 18.10 & 1.99 & -0.12 & 2.94 \\
\hline 18.30 & 0.93 & -0.30 & 3.02 \\
\hline 18.53 & 8.40 & -0.06 & 3.26 \\
\hline 18.65 & 4.39 & -0.04 & 3.39 \\
\hline 18.80 & 0.05 & -0.02 & 3.49 \\
\hline 19.10 & 0.19 & -0.02 & 3.54 \\
\hline 19.31 & 0.58 & 0.19 & 3.57 \\
\hline 19.50 & 2.98 & 0.38 & 3.61 \\
\hline 19.75 & 4.22 & 0.58 & 3.56 \\
\hline 19.92 & 2.01 & 0.61 & 3.35 \\
\hline 20.10 & 1.18 & 0.49 & 3.03 \\
\hline 20.31 & 3.83 & 0.45 & 2.84 \\
\hline 20.50 & 2.33 & 0.36 & 2.38 \\
\hline 20.69 & 0.36 & 0.18 & 2.69 \\
\hline 20.90 & 0.17 & 0.15 & 3.07 \\
\hline 21.02 & 0.65 & 0.13 & 3.25 \\
\hline 21.21 & 9.87 & 0.08 & 3.64 \\
\hline 21.40 & 4.13 & 0.05 & 4.09 \\
\hline 21.80 & 8.01 & 0.20 & 4.29 \\
\hline 22.01 & 2.72 & -0.03 & 4.29 \\
\hline 22.40 & 5.99 & -0.57 & 4.70 \\
\hline 22.60 & 3.10 & -0.40 & 3.77 \\
\hline
\end{tabular}


Appendix B (continued)

\begin{tabular}{|c|c|c|c|}
\hline $\begin{array}{l}\text { Depth } \\
\text { (mbsf) }\end{array}$ & $\begin{array}{c}>63 \mu \mathrm{m} \\
(8)\end{array}$ & $\begin{array}{c}\delta^{18} 0 \\
(0 / 00)\end{array}$ & $\begin{array}{l}\delta^{13} \mathrm{C} \\
\left({ }^{\circ} / 00\right)\end{array}$ \\
\hline 22.84 & 2.33 & -0.28 & 4.04 \\
\hline 23.01 & 2.60 & -0.24 & 4.23 \\
\hline 23.18 & 15.01 & -0.20 & 4.24 \\
\hline 23.32 & 6.53 & -0.16 & 4.27 \\
\hline 23.50 & 5.69 & -0.31 & 4.05 \\
\hline 23.70 & 6.91 & -0.52 & 3.42 \\
\hline 23.91 & 8.05 & 0.04 & 4.43 \\
\hline 23.99 & 2.73 & -0.15 & 3.71 \\
\hline 24.20 & 5.13 & 0.00 & 3.84 \\
\hline 24.49 & 3.01 & 0.22 & 3.85 \\
\hline 24.71 & 1.31 & 0.31 & 4.45 \\
\hline 24.93 & 0.55 & 0.41 & 4.14 \\
\hline 25.35 & 4.11 & 0.25 & 3.93 \\
\hline 25.52 & 1.05 & 0.22 & 3.88 \\
\hline 25.73 & 2.51 & 0.13 & 3.80 \\
\hline 25.99 & 3.50 & 0.23 & 3.59 \\
\hline 26.20 & 1.00 & 0.30 & 3.91 \\
\hline 26.35 & 6.31 & 0.46 & 3.96 \\
\hline 26.62 & 7.60 & -0.08 & 3.34 \\
\hline 26.80 & 3.00 & 0.01 & 3.14 \\
\hline 26.97 & 0.85 & 0.26 & 2.80 \\
\hline 27.13 & 6.79 & 0.29 & 2.32 \\
\hline 27.29 & 5.72 & 0.32 & 2.51 \\
\hline 27.49 & 1.54 & 0.52 & 2.89 \\
\hline 27.62 & 1.28 & 0.59 & 2.58 \\
\hline 27.89 & 0.60 & 0.05 & 2.99 \\
\hline 28.10 & 0.59 & -0.03 & 2.67 \\
\hline 28.28 & 0.18 & -0.08 & 2.62 \\
\hline 28.50 & 0.19 & -0.17 & 2.24 \\
\hline 28.71 & 0.23 & -0.19 & 2.41 \\
\hline 28.92 & 0.36 & -0.20 & 2.36 \\
\hline 29.19 & 12.59 & -0.25 & 2.31 \\
\hline 29.40 & 10.01 & -0.26 & 2.24 \\
\hline 29.59 & 2.38 & -0.29 & 3.25 \\
\hline 29.80 & 3.20 & -0.32 & 4.04 \\
\hline 30.00 & 2.43 & -0.35 & 3.94 \\
\hline 30.20 & 8.54 & -0.11 & 3.71 \\
\hline 30.41 & 2.78 & 0.21 & 3.80 \\
\hline 30.70 & 5.22 & 0.13 & 3.97 \\
\hline 30.90 & 3.11 & 0.45 & 4.08 \\
\hline 31.09 & 15.09 & 0.60 & 4.10 \\
\hline 31.29 & 6.99 & 0.56 & 3.99 \\
\hline 31.49 & 2.39 & 0.51 & 3.26 \\
\hline 31.69 & 4.50 & 0.80 & 3.05 \\
\hline 31.88 & 3.21 & 0.51 & 3.26 \\
\hline 32.20 & 6.30 & 0.60 & 3.82 \\
\hline 32.40 & 1.22 & 0.75 & 3.10 \\
\hline 32.70 & 1.02 & 0.71 & 2.68 \\
\hline 32.80 & 1.03 & 0.70 & 2.55 \\
\hline 32.99 & 1.00 & 0.59 & 2.75 \\
\hline 33.20 & 0.81 & 0.48 & 2.13 \\
\hline 33.37 & 0.98 & 0.21 & 2.26 \\
\hline 33.57 & 0.39 & 0.75 & 1.88 \\
\hline 33.79 & 0.06 & 0.16 & 1.87 \\
\hline 33.92 & 1.00 & -0.19 & 1.85 \\
\hline 34.18 & 0.54 & -0.09 & 2.57 \\
\hline 34.30 & 1.29 & 0.55 & 2.42 \\
\hline 34.45 & 0.95 & 0.34 & 1.85 \\
\hline 34.68 & 0.82 & 0.24 & 2.50 \\
\hline
\end{tabular}

\begin{tabular}{|c|c|c|c|}
\hline $\begin{array}{l}\text { Depth } \\
\text { (mbsf) }\end{array}$ & $\begin{array}{c}>63 \mu \mathrm{m} \\
(8)\end{array}$ & $\begin{array}{l}\delta^{18} 0 \\
(\% / 00)\end{array}$ & $\begin{array}{l}\delta^{13} \mathrm{C} \\
\left({ }^{\circ} / 00\right)\end{array}$ \\
\hline 34.88 & 0.70 & 0.54 & 2.43 \\
\hline 35.08 & 2.63 & 0.45 & 2.61 \\
\hline 35.29 & 1.92 & 0.25 & 2.40 \\
\hline 35.44 & 3.61 & 0.17 & 3.00 \\
\hline 35.65 & 0.89 & 0.10 & 2.79 \\
\hline 35.80 & 1.02 & 0.03 & 2.80 \\
\hline 35.97 & 1.05 & -0.13 & 2.75 \\
\hline 36.07 & 1.09 & -0.24 & 3.42 \\
\hline 36.20 & 1.11 & -0.31 & 3.59 \\
\hline 36.40 & 14.03 & -0.26 & 3.55 \\
\hline 36.58 & 11.00 & -0.35 & 3.74 \\
\hline 36.78 & 14.99 & -0.55 & 3.86 \\
\hline 36.94 & 13.55 & -0.44 & 3.97 \\
\hline 37.17 & 6.29 & -0.25 & 4.14 \\
\hline 37.28 & 6.30 & -0.17 & 4.26 \\
\hline 37.48 & 1.26 & -0.09 & 4.50 \\
\hline 37.59 & 6.85 & -0.10 & 4.55 \\
\hline 37.69 & 4.99 & -0.05 & 4.50 \\
\hline 37.90 & 2.91 & 0.02 & 4.26 \\
\hline 38.05 & 5.20 & 0.01 & 3.98 \\
\hline 38.24 & 4.84 & -0.01 & 3.57 \\
\hline 38.47 & 15.00 & 0.00 & 3.88 \\
\hline 38.66 & 8.80 & 0.05 & 4.20 \\
\hline 38.80 & 9.98 & 0.07 & 3.83 \\
\hline 38.98 & 8.84 & 0.15 & 4.00 \\
\hline 39.00 & 7.73 & 0.22 & 3.32 \\
\hline 39.20 & 10.95 & 0.25 & 3.48 \\
\hline 39.30 & 4.00 & 0.27 & 3.57 \\
\hline 39.50 & 4.80 & 0.30 & 2.75 \\
\hline 39.70 & 8.06 & 0.39 & 3.82 \\
\hline 39.91 & 3.10 & 0.75 & 3.07 \\
\hline 40.10 & 1.59 & 0.72 & 3.87 \\
\hline 40.33 & 1.68 & 0.30 & 2.24 \\
\hline 40.50 & 1.03 & 0.82 & 1.96 \\
\hline 40.70 & 1.80 & 0.56 & 2.14 \\
\hline 40.80 & 1.92 & 0.60 & 1.79 \\
\hline 41.00 & 3.13 & 0.59 & 2.79 \\
\hline 41.10 & 3.42 & 0.61 & 2.01 \\
\hline 41.20 & 4.39 & 0.74 & 1.79 \\
\hline 41.40 & 5.09 & 0.70 & 2.12 \\
\hline 41.60 & 3.05 & 0.62 & 2.86 \\
\hline 41.79 & 2.14 & 0.68 & 1.91 \\
\hline 41.99 & 3.27 & 0.58 & 2.75 \\
\hline 42.20 & 2.09 & 0.62 & 3.79 \\
\hline 42.30 & 2.10 & 0.24 & 3.52 \\
\hline 42.44 & 2.00 & 0.86 & 3.82 \\
\hline 42.79 & 1.79 & 0.72 & 3.45 \\
\hline 42.89 & 4.29 & 0.66 & 3.57 \\
\hline 43.10 & 2.33 & 0.28 & 3.78 \\
\hline 43.30 & 2.26 & 0.50 & 3.57 \\
\hline 43.49 & 2.49 & 0.30 & 3.72 \\
\hline 43.70 & 3.25 & 0.25 & 3.46 \\
\hline 43.80 & 3.31 & 0.21 & 3.73 \\
\hline 44.00 & 4.30 & 0.13 & 2.98 \\
\hline 44.10 & 3.62 & 0.05 & 2.98 \\
\hline 44.20 & 3.00 & 0.25 & 3.32 \\
\hline 44.40 & 7.52 & 0.22 & 3.01 \\
\hline 44.61 & 3.78 & 0.15 & 2.84 \\
\hline 44.75 & 3. 32 & 0.09 & 2.74 \\
\hline
\end{tabular}




\begin{tabular}{|c|c|c|c|}
\hline $\begin{array}{l}\text { Depth } \\
\text { (mbsf) }\end{array}$ & $\begin{array}{c}>63 \mu \mathrm{m} \\
(8)\end{array}$ & $\begin{array}{c}\delta^{18} 0 \\
\left({ }^{\circ} / 00\right)\end{array}$ & $\begin{array}{l}\delta^{13} \mathrm{C} \\
\left({ }^{\circ} / 00\right)\end{array}$ \\
\hline 44.98 & 5.18 & 0.04 & 3.03 \\
\hline 45.21 & 5.43 & -0.03 & 3.69 \\
\hline 45.30 & 10.00 & -0.12 & 3.80 \\
\hline 45.50 & 7.11 & 0.40 & 4.13 \\
\hline 45.60 & 5.59 & 0.35 & 4.54 \\
\hline 45.70 & 7.00 & 0.34 & 4.57 \\
\hline 45.90 & 3.94 & -0.12 & 3.64 \\
\hline 46.08 & 12.12 & 0.10 & 3.87 \\
\hline 46.30 & 6.17 & 0.42 & 4.41 \\
\hline 46.90 & 5.09 & -0.13 & 3.09 \\
\hline 47.10 & 2.39 & -0.27 & 2.70 \\
\hline 47.30 & 10.05 & 0.01 & 2.99 \\
\hline 47.50 & 7.13 & 0.04 & 2.88 \\
\hline 47.70 & 3.80 & 0.34 & 2.62 \\
\hline 47.89 & 5.16 & -0.12 & 2.46 \\
\hline 48.02 & 1.12 & -0.60 & 2.07 \\
\hline 48.24 & 3.58 & -0.21 & 2.45 \\
\hline 48.40 & 4.65 & -0.39 & 2.11 \\
\hline 48.56 & 5.49 & -0.46 & 2.06 \\
\hline 48.80 & 0.37 & -0.35 & 2.64 \\
\hline 49.00 & 0.90 & -0.26 & 2.58 \\
\hline 49.18 & 0.42 & -0.37 & 2.30 \\
\hline 49.39 & 0.93 & 0.30 & 3.28 \\
\hline 49.68 & 3.41 & 0.10 & 2.80 \\
\hline 49.99 & 9.09 & 0.13 & 3.00 \\
\hline 50.00 & 7.97 & 0.28 & 3.44 \\
\hline 50.20 & 2.05 & 0.35 & 3.52 \\
\hline 50.40 & 1.34 & -0.31 & 3.12 \\
\hline 50.59 & 1.40 & -0.32 & 2.77 \\
\hline 50.80 & 0.44 & -0.18 & 2.74 \\
\hline 51.00 & 1.96 & 0.25 & 2.91 \\
\hline 51.21 & 7.21 & -0.25 & 3.57 \\
\hline 51.39 & 2.55 & -0.34 & 3.71 \\
\hline 51.50 & 10.21 & -0.49 & 3.41 \\
\hline 51.70 & 5.03 & -0.57 & 3.59 \\
\hline 51.90 & 9.80 & -0.90 & 3.90 \\
\hline 52.10 & 5.51 & -0.25 & 4.34 \\
\hline 52.29 & 2.71 & -0.51 & 4.04 \\
\hline 52.50 & 8.01 & -0.69 & 4.70 \\
\hline 52.78 & 4.41 & -0.29 & 4.51 \\
\hline 52.90 & 11.39 & -0.25 & 4.23 \\
\hline 53.04 & 9.87 & -0.50 & 4.21 \\
\hline 53.20 & 2.79 & -0.24 & 4.34 \\
\hline 53.39 & 4.60 & -0.69 & 3.88 \\
\hline 53.60 & 4.22 & -0.35 & 4.10 \\
\hline 53.80 & 3.55 & -0.70 & 4.09 \\
\hline 54.00 & 3.99 & -0.35 & 3.74 \\
\hline 54.20 & 3.77 & -1.00 & 3.70 \\
\hline 54.38 & 10.30 & -0.29 & 4.06 \\
\hline 54.47 & 7.48 & -0.34 & 4.02 \\
\hline 54.70 & 5.23 & -0.47 & 3.94 \\
\hline 54.87 & 1.04 & -0.60 & 3.85 \\
\hline 55.08 & 8.12 & -0.35 & 3.64 \\
\hline 55.30 & 5.54 & -0.90 & 3.60 \\
\hline 55.50 & 4.21 & 0.10 & 3.12 \\
\hline 55.70 & 2.82 & 0.35 & 2.74 \\
\hline 55.87 & 1.75 & 0.26 & 2.50 \\
\hline 56.04 & 1.68 & 0.17 & 3.88 \\
\hline 56.18 & 0.77 & -0.08 & 2.84 \\
\hline
\end{tabular}

\begin{tabular}{|c|c|c|c|}
\hline $\begin{array}{l}\text { Depth } \\
\text { (mbsf) }\end{array}$ & $\begin{array}{c}>63 \mu \mathrm{m} \\
(8)\end{array}$ & $\begin{array}{c}\delta^{18} 0 \\
(0 / 00)\end{array}$ & $\begin{array}{l}\delta^{13} \mathrm{C} \\
\left({ }^{\circ} / \circ 0\right)\end{array}$ \\
\hline 56.40 & 0.56 & 0.02 & 2.76 \\
\hline 56.60 & 0.30 & 0.05 & 2.50 \\
\hline 56.80 & 0.79 & 0.10 & 2.66 \\
\hline 57.00 & 0.69 & -0.05 & 2.59 \\
\hline 57.20 & 0.85 & -0.04 & 2.50 \\
\hline 57.40 & 1.13 & -0.05 & 2.74 \\
\hline 57.50 & 1.00 & 0.00 & 2.44 \\
\hline 57.59 & 0.31 & 0.00 & 2.29 \\
\hline 57.90 & 0.99 & -0.05 & 2.75 \\
\hline 58.08 & 0.65 & -0.47 & 2.71 \\
\hline 58.29 & 0.94 & -0.40 & 3.10 \\
\hline 58.50 & 1.79 & -0.29 & 2.81 \\
\hline 58.68 & 0.95 & 0.00 & 2.64 \\
\hline 58.78 & 1.29 & -0.31 & 3.14 \\
\hline 59.00 & 1.59 & -0.20 & 3.34 \\
\hline 59.19 & 10.44 & -0.72 & 3.66 \\
\hline 59.60 & 11.00 & -0.49 & 3.59 \\
\hline 59.85 & 1.59 & -0.34 & 3.55 \\
\hline 60.03 & 3.38 & -0.40 & 3.48 \\
\hline 60.20 & 6.40 & -0.42 & 3.33 \\
\hline 61.20 & 2.00 & -0.42 & 3.45 \\
\hline 62.01 & 10.74 & -0.52 & 3.85 \\
\hline 62.23 & 3.85 & -0.63 & 3.92 \\
\hline 62.51 & 0.70 & -0.95 & 3.46 \\
\hline 62.61 & 3.68 & -0.68 & 3.40 \\
\hline 62.83 & 2.00 & -0.26 & 3.25 \\
\hline 63.00 & 2.59 & -0.35 & 3.49 \\
\hline 63.25 & 9.50 & -0.38 & 3.92 \\
\hline 63.44 & 2.97 & 0.08 & 2.64 \\
\hline 63.69 & 5.61 & -0.29 & 2.56 \\
\hline 63.83 & 2.95 & -0.37 & 2.41 \\
\hline 64.01 & 2.05 & -0.74 & 2.15 \\
\hline 64.14 & 2.32 & -0.98 & 1.64 \\
\hline 64.38 & 0.55 & -0.30 & 2.68 \\
\hline 64.50 & 2.60 & -0.69 & 2.79 \\
\hline 64.74 & 6.39 & -0.58 & 3.66 \\
\hline 64.95 & 7.88 & -0.45 & 3.23 \\
\hline 65.15 & 15.03 & -0.11 & 4.27 \\
\hline 65.35 & 12.51 & 0.15 & 4.19 \\
\hline 65.53 & 4.54 & 0.08 & 3.25 \\
\hline 65.65 & 5. 34 & 0.09 & 3.42 \\
\hline 65.80 & 6.40 & 0.10 & 3.25 \\
\hline 66.00 & 6.09 & 0.06 & 3.00 \\
\hline 66.23 & 9.17 & -0.07 & 2.99 \\
\hline 66.42 & 11.78 & -0.26 & 3.17 \\
\hline 66.67 & 5.19 & -0.65 & 3.13 \\
\hline 66.82 & 3.70 & -1.29 & 2.72 \\
\hline 67.03 & 9.93 & -0.50 & 2.83 \\
\hline 67.10 & 5.76 & -0.46 & 2.84 \\
\hline 67.30 & 6.29 & -0.41 & 2.45 \\
\hline 67.52 & 1.60 & -0.21 & 3.25 \\
\hline 67.72 & 12.47 & -0.29 & 3.14 \\
\hline 67.90 & 6.79 & -1.06 & 2.74 \\
\hline 68.13 & 4.65 & -1.12 & 2.62 \\
\hline 68.31 & 2.69 & -1.04 & 2.30 \\
\hline 68.58 & 5.22 & -0.72 & 2.59 \\
\hline 68.64 & 15.00 & -0.90 & 2.54 \\
\hline 68.80 & 10.06 & -0.82 & 2.66 \\
\hline 69.03 & 12.00 & -0.69 & 2.90 \\
\hline
\end{tabular}




\section{Appendix B (continued)}

\begin{tabular}{|c|c|c|c|}
\hline $\begin{array}{l}\text { Depth } \\
\text { (mbsf) }\end{array}$ & $\begin{array}{c}>63 \mu \mathrm{m} \\
(8)\end{array}$ & $\begin{array}{c}\delta^{18} 0 \\
(0 / 00)\end{array}$ & $\begin{array}{l}\delta^{13} \mathrm{C} \\
\left({ }^{0} / 0_{0}\right)\end{array}$ \\
\hline 69.22 & 11.20 & -0.58 & 3.08 \\
\hline 69.41 & 12.74 & -0.49 & 3.20 \\
\hline 69.52 & 5.68 & -0.44 & 3.37 \\
\hline 69.75 & 5.15 & -0.30 & 3.57 \\
\hline 69.96 & 0.97 & -0.24 & 3.65 \\
\hline 70.19 & 1.02 & -0.30 & 3.70 \\
\hline 70.30 & 1.29 & -0.31 & 3.64 \\
\hline 70.51 & 6.80 & -0.15 & 3.70 \\
\hline 70.75 & 0.89 & -0.65 & 3.70 \\
\hline 70.89 & 4.20 & -0.69 & 3.70 \\
\hline 71.04 & 0.55 & -0.34 & 3.78 \\
\hline 71.20 & 3.10 & -0.59 & 3.71 \\
\hline 71.49 & 14.85 & -0.80 & 3.79 \\
\hline 71.68 & 6.86 & -0.72 & 3.53 \\
\hline 71.88 & 3.80 & -0.65 & 3.23 \\
\hline 72.05 & 1.31 & -0.56 & 3.97 \\
\hline 72.23 & 0.30 & -0.50 & 2.71 \\
\hline 72.35 & 0.60 & -0.60 & 2.90 \\
\hline 72.50 & 1.20 & 0.00 & 3.41 \\
\hline 72.72 & 2.52 & -0.10 & 3.15 \\
\hline 72.95 & 4.90 & 0.00 & 3.18 \\
\hline 73.14 & 9.06 & 0.04 & 3.24 \\
\hline 73.31 & 3.19 & 0.04 & 3.25 \\
\hline 73.56 & 1.29 & 0.25 & 2.89 \\
\hline 73.75 & 5.20 & -0.11 & 2.64 \\
\hline 74.04 & 0.20 & -0.33 & 2.09 \\
\hline 74.20 & 0.21 & -0.41 & 1.70 \\
\hline 74.40 & 0.83 & -0.30 & 2.14 \\
\hline 74.60 & 14.98 & -0.21 & 2.37 \\
\hline 74.85 & 13.70 & -0.06 & 2.92 \\
\hline 75.04 & 3.53 & -0.08 & 3.29 \\
\hline 75.30 & 0.91 & 0.25 & 3.76 \\
\hline 75.40 & 1.68 & 0.30 & 3.89 \\
\hline 75.68 & 1.66 & 0.01 & 4.13 \\
\hline 75.70 & 5.13 & 0.27 & 3.77 \\
\hline 75.91 & 1.15 & 0.40 & 3.28 \\
\hline
\end{tabular}

\begin{tabular}{lrrr}
$\begin{array}{l}\text { Depth } \\
\text { (mbsf) }\end{array}$ & $\begin{array}{c}>3 \mu \mathrm{m} \\
(8)\end{array}$ & $\begin{array}{c}\left.\delta^{18} \mathrm{O}\right) \\
(\% \circ)\end{array}$ & $\begin{array}{c}\delta^{13} \mathrm{C} \\
\left({ }^{\circ} / 00\right.\end{array}$ \\
\hline 76.12 & 1.38 & 0.59 & 3.36 \\
76.30 & 5.60 & 0.32 & 3.50 \\
76.53 & 4.99 & 0.34 & 3.43 \\
76.70 & 1.55 & 0.36 & 3.36 \\
76.92 & 4.75 & 0.41 & 3.26 \\
77.13 & 6.11 & 0.45 & 3.16 \\
77.20 & 7.70 & 0.46 & 3.14 \\
77.40 & 1.82 & 0.49 & 3.06 \\
77.62 & 0.69 & 0.50 & 3.05 \\
77.82 & 1.34 & 0.54 & 2.99 \\
78.00 & 2.35 & 0.29 & 3.09 \\
78.21 & 3.65 & 0.31 & 3.40 \\
78.40 & 1.26 & 0.32 & 3.53 \\
78.60 & 1.51 & 0.05 & 3.41 \\
78.70 & 3.17 & 0.09 & 3.54 \\
78.91 & 6.56 & 0.23 & 3.65 \\
79.12 & 1.60 & 0.72 & 3.54 \\
79.32 & 12.06 & 0.67 & 3.49 \\
79.50 & 4.12 & 0.63 & 3.40 \\
79.70 & 0.99 & 0.56 & 3.21 \\
79.90 & 0.91 & 0.51 & 3.24 \\
80.10 & 0.84 & 0.46 & 3.12 \\
80.20 & 1.57 & 0.14 & 3.03 \\
80.40 & 2.50 & 0.04 & 3.51 \\
80.60 & 4.09 & 0.04 & 3.60 \\
80.80 & 2.98 & 0.05 & 3.69 \\
81.00 & 0.65 & 0.05 & 3.76 \\
81.20 & 0.78 & 0.05 & 3.82 \\
81.41 & 0.89 & -0.06 & 3.74 \\
81.60 & 5.74 & -0.15 & 3.65 \\
81.72 & 12.06 & -0.14 & 3.87 \\
81.90 & 7.82 & -0.12 & 4.33 \\
82.10 & 7.85 & -0.10 & 4.64 \\
83.60 & 0.21 & 0.04 & 4.18 \\
85.10 & 1.13 & -0.25 & 3.62 \\
& & &
\end{tabular}


APPENDIX C

Oxygen and carbon isotopic data for $N$. pachyderma and $>63-\mu \mathrm{m}$ data for Hole 647A.

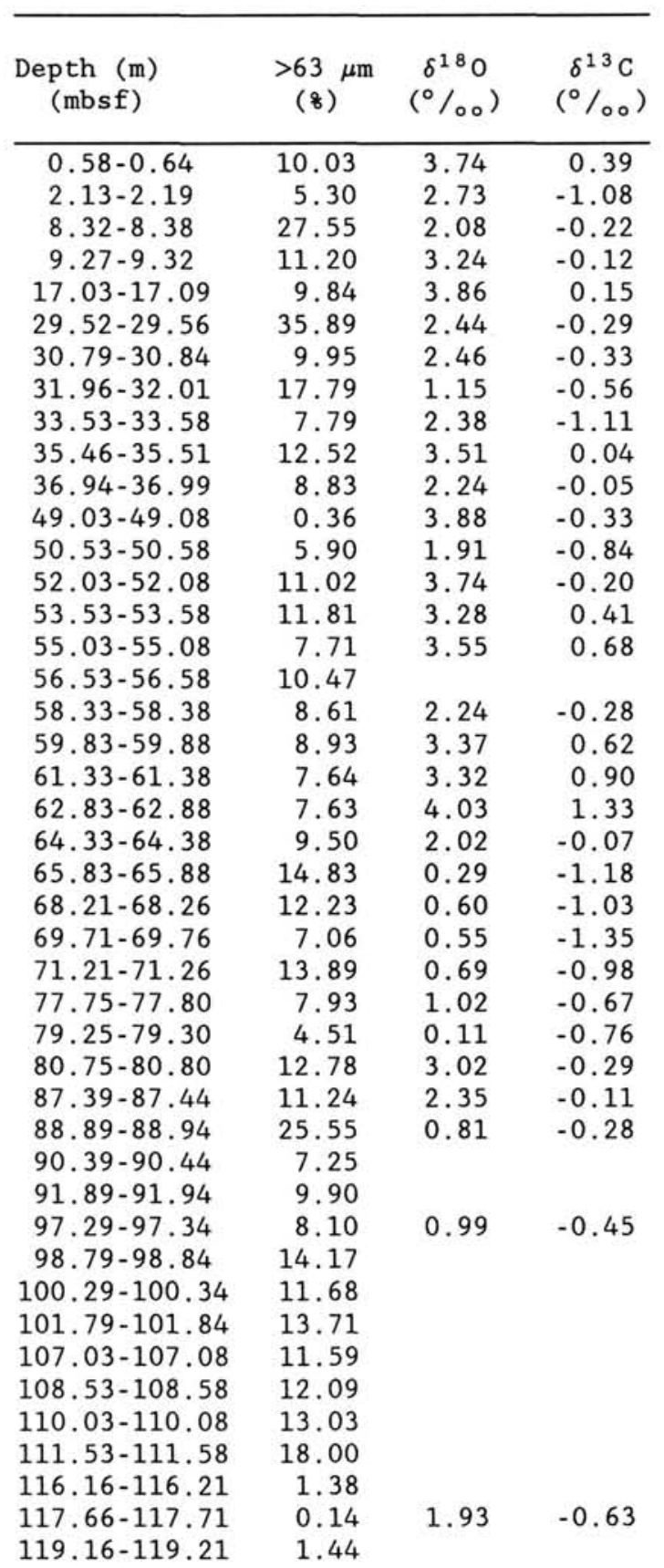

